Historic, Archive Document

Do not assume content reflects current scientific knowledge, policies, or practices. 



\subsection{3}

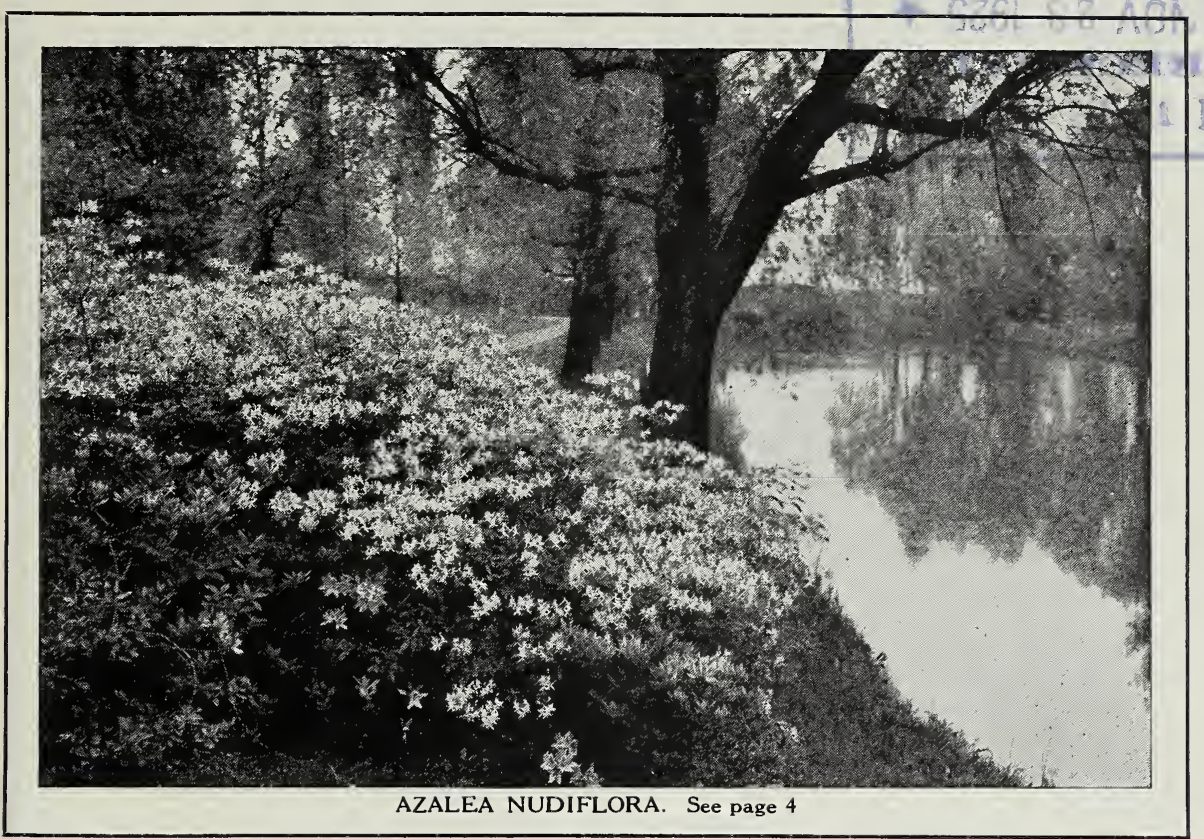

FALL 1925

SPRING 1926

\section{NATIVE BROAD-LEAVED}

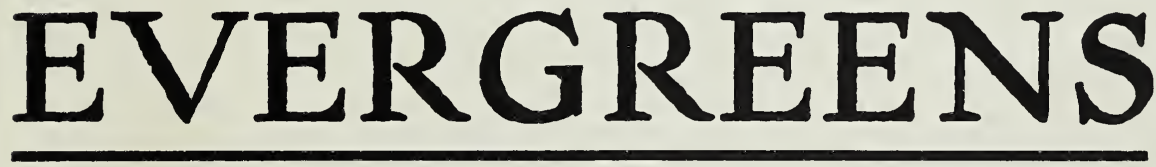

\section{FOR IMMEDIATE EFFECT}

And Many Other Specialties for Fall and Spring Planting. Exceptional Quotations on Large Lists Submitted. My supply and facilities are unequaled, and backed up by 33 years' constant experience growing and handling Hardy Native Ornamentals which should recommend the favor of your orders

no

\section{GaRdens OF THE Blue Ridge}

\section{E. C. ROBBINS, Ornamental}

NOTE NEW AND PERMANENT ADDRESS 


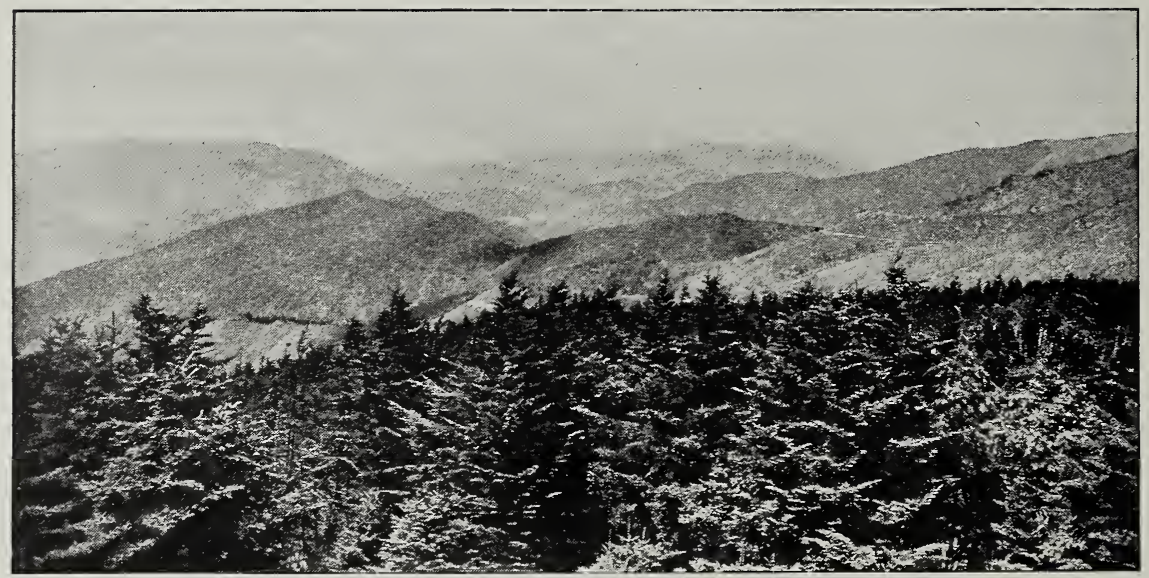

The celebrated Blue Ridge Mountains, near Ashford, N. C.

\section{Note to Customers}

\section{NEW LOCATION}

Is in the heart of the Blue Ridge Mountains, "the most beautiful mountain region of the continent," in western North Carolina, nearly 4,000 feet above sealevel. My new and permanent headquarters is Ashford, McDowell County, North Carolina, on the scenic Clinchfreld Railroad.

All offers of stock are made subject to conditions beyond my control

\section{PACKING AND GRADING}

Will be done in the most careful way. Boxing and burlapping included at prices named. Certificate of Inspection attached to all shipments.

\section{QUOTATIONS}

This list cancels previous offers and prices quoted are net and not subject to discount except by special agreement.

\section{REMITTANCE OR REFERENCE}

Should accompany orders from unknown correspondents. Discount of 5 per cent on cash orders. All bills due and payable 30 days from date of invoice. Interest charged after 30 days.

\section{SHIPPING INSTRUCTIONS}

Should always be given fully, unless you prefer to leave to our best judgment. In this we assume no risk, our responsibility ceasing upon receipt of signed bill of lading by forwarders. All claims for damages in transit must be handled by consignee.

\section{CLAIMS}

AII claims for errors must be reported upon receipt of goods and will be rectifred promptly. Unless this is done we can accept no responsibility of any kind.

\section{ALL ORDERS}

Are accepted and filled on these terms, unless otherwise agreed. 


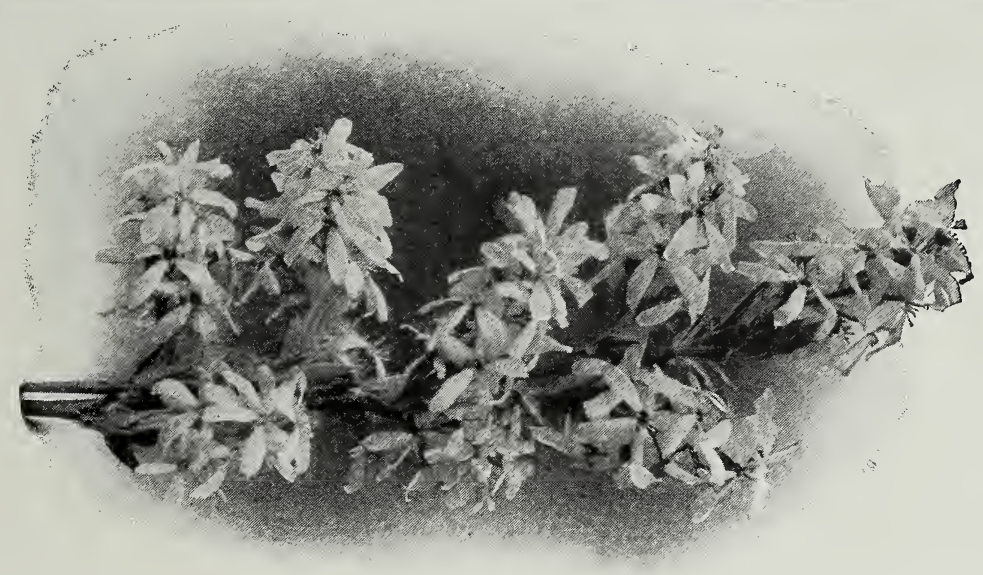

Flowers of Amelanchier canadensis

\section{Hardy Deciduous Trees and Shrubs}

ACER saccharum. Sugar Maple. Handsome, rapid-growing io tree for general use. Splendid fall coloring of foliage.

I to 2 feet. Strong, select trees.................. \$I 25 \$10 oo

2 to 3 feet. $X$ select................... 2 oo I7 50

3 to 4 feet. $\mathrm{X}$ select...................... 5 oo 40 oo

4 to 6 feet. Specimen trees................ 750

ALNUS viridis. European Green Alder. Low shrub, with at-

tractive foliage. From high altitudes. I to 2 feet... 4 oo

2 to 3 feet. Strong, stocky plants.............. 6 oo

AMELANCHIER canadensis. Downy Serviceberry. Very handsome early-flowering small tree. Snow-white flowers, appearing in early spring. Fruit edible and ripening in July. 6 to 12 inches. Strong established. I 20

I to 2 feet. Strong transplanted................ 225

2 to 3 feet. Strong transplanted, stocky........... 4 oo

3 to 4 feet. Strong transplanted, stocky.............6 60

4 to 6 feet. Strong transplanted, stocky. Each $\$ 1.25 \ldots$ Io oo

ARALIA spinosa. Devil's Walking-Stick. Prickly stemmed low tree or shrub with large compound foliage and large panicles of showy white flowers in midsummer.

I to 2 feet. Strong plants................. 3 oo

ARONIA arbutifolia. Red Chokeberry. Large-flowering shrub, with clusters of red berries in autumn and early winter. I to 2 feet. Strong, stocky plants....... 275

melanocarpa. Black Chokeberry. A very desirable orna-
mental shrub. White flowers in early spring, with clusters of black fruit in autumn and early winter. Foliage colors dark red in early fall.

I to 2 feet. Extra-heavy stocky plants.......... 350

2 to 3 feet. Extra-heavy stocky plants............ 450

AZALEA arborescens. Sweet White Azalea. Large, fragrant white flowers in early summer. Of easy culture and lasting beauty.

9 to 12 inches. $X$ strong bushy plants........... 8 oo

I to 2 feet. XX strong bushy plants............ I5 oo

2 to 3 feet. XXX heavy clumps................... $\$ 45$ oo

One-year heavy transplanted clumps.............. 650 


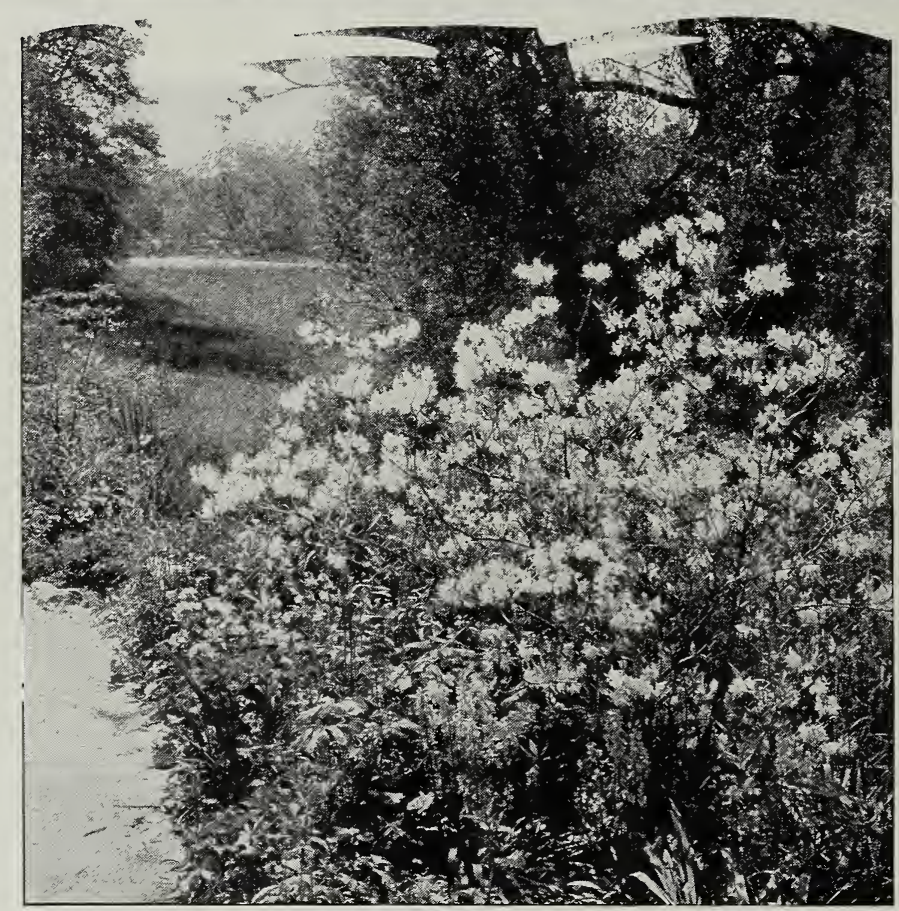

Azalea Vaseyi

HARDY DECIDUOUS TREES AND SHRUBS, continued

Azalea calendulacea. Flame Azalea. The most beautiful and
varied species of all native Azaleas. All the way in ro I00

I, 000 color from orange to canary and very conspicuous in early summer throughout the Carolina Mountains.

8 to 12 inches. $\mathrm{X}$ heavy transplanted............. $\$ 8$ oo

$\mathrm{I}$ to 2 feet. XX heavy select clumps............... 250

2 to 3 feet. XXX heavy select stocky clumps......... 15 oo

3 to 4 feet. XXX heavy select stocky clumps.........

Each $\$ 2.50 \ldots 20$ oo

Heavy 1-yr. trans. cut-back clumps for growing on....6 60

$\$ 7500$

100 o0

13500

I 8500

canescens $(A$. rosea $)$. Piedmont Azalea. Excellent rare species. Very similar to Azalea Vaseyi.

9 to 12 inches. Heavy clumps............... 8 oo

I to 2 feet. Very select heavy clumps.... Each $\$$ I.20. . IO 00

One-year cut-back heavy clumps for growing on. Very special bargain........................ 750

nudiflora. Pinxter Bloom. Very handsome free-flowering shrub. Deep pink; profuse and showy.

9 to 12 inches. Heavy established clumps.......... Io oo

I 2 to 18 inches. Heavy established, good value........ I5 oo

Heavy one-year cut-back clumps for growing on........6 60

Vaseyi. Pinkshell Azalea. A distinct and remarkably free-

60 oo $\$ 500$ oo

75 oo

90 oo

700 oo

$6500+60000$

$6500 \quad 60000$

85 o0 $\quad 800$ o0

135 o0 1250 o0

50 oo 450 oo

flowering hardy shrub of extreme rarity and beauty. The flowers are of an exquisite shade of pink or rose, appearing in profusion before the leaves unfold in early spring. In autumn the foliage assumes deep rich shades of red and crimson. Very attractive ornamental shrub.

9 to $\mathrm{I} 2$ inches. Transplanted and grown in nursery.... Io oo 85 oo

I2 to I 8 inches. Heavy transplanted.............25 o0 225 o0

One-year heavy transplanted clumps, for growing on... 8 oo 75 oo 


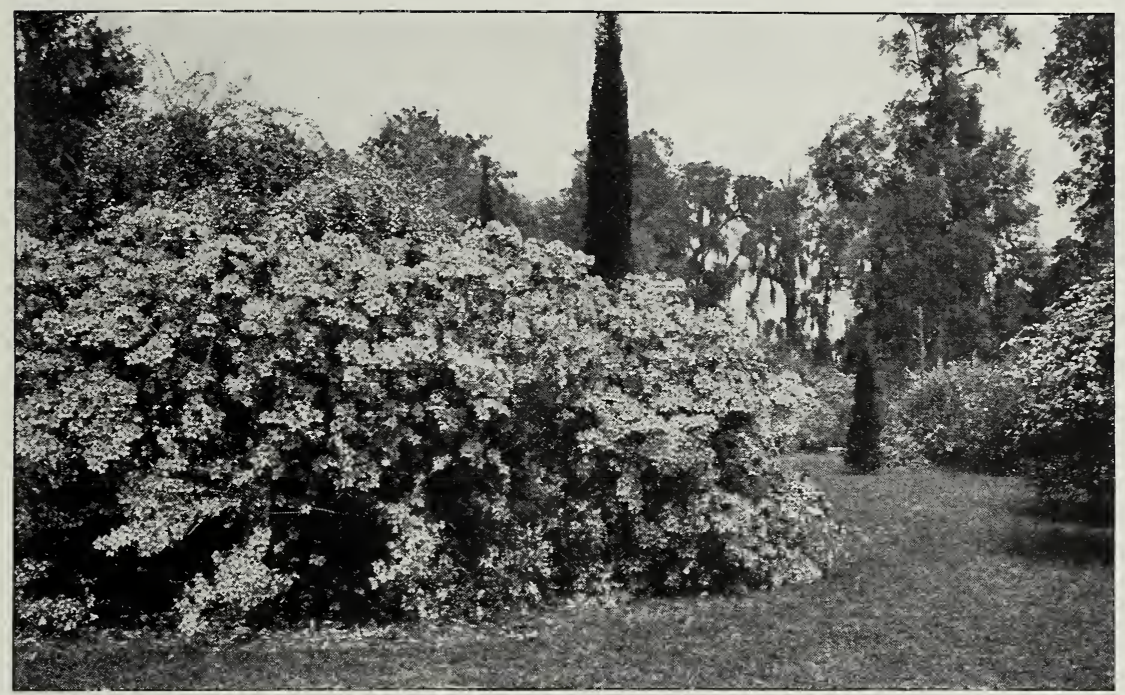

Azalea calendulacea. See page 4

\section{HARDY DECIDUOUS TREES AND SHRUBS, continued}

Azalea viscosa. Swamp Azalea. White; fragrant. Late- ro 100 blooming, thriving well along streams.

9 to 12 inches. Heavy transplanted..............\$6 oo $\$ \$ 50$ oo

I to 2 feet. Heavy transplanted............... 8 oo 75 oo

One-year heavy transplanted cut-back clumps...... 5 oо 45 oo

CASTANEA dentata. American Chestnut. Large, admirable shade tree, bearing edible nuts.

8 to $\mathrm{I} 2$ inches. Strong nursery-grown seedlings....... I oo

COMPTONIA asplenifolia. Sweet Fern. Fine shrub, with sweet-scented leaves. Easy of culture and succeeds well on dry upland. I to 2 feet. Strong plants.... 2502000

CORYLUS americana. American Hazelnut. Vigorous-growing and very ornamental shrub, bearing edible nuts which are very desirable.

I to 2 feet. Strong plants................ I 25 Io 00

rostrata. Beaked Hazelnut. Smaller than above species and equally as desirable.

I to 2 feet. Strong, stocky plants............ 2 oo I7 50

2 to 3 feet. Heavy, stocky plants............... 3 oo 25 oo

CYTISUS scoparius. Scotch Broom. Strange, interesting shrub. Bright yellow flowers in great profusion.

I to $I \frac{1}{2}$ feet. Strong nursery-grown seedlings........ I 25 Iо $00 \quad \$ 85$ o0

I $1 / 2$ to 2 feet. Strong nursery-grown seedlings......... 2 Oo $1750 \quad 150$

DIERVILLA sessilifolia. Southern Bush Honeysuckle. Very handsome shrub, with spreading branches and clusters of yellow terminal flowers.

I to 2 feet. Strong plants................... 3750

GENISTA tinctoria. Woadwaxen. Low, spreading shrub, with green branches covered with yellow flowers in summer. Excellent rock-garden subject.

9 to 12 inches. Strong nursery-grown seedlings....... I oo 8 oo $\quad 7500$ 


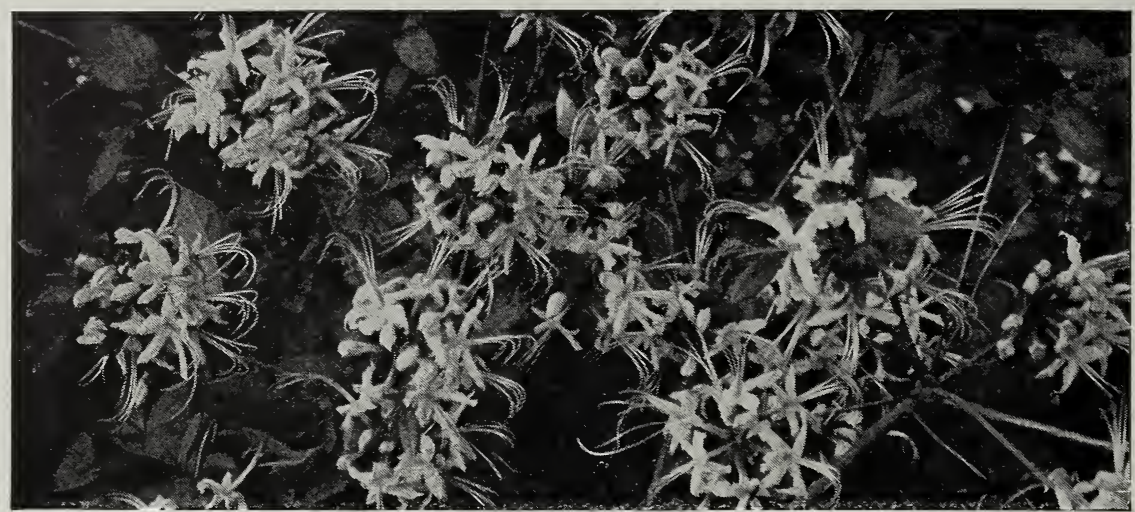

Azalea canescens. See page 4

\section{HARDY DECIDUOUS TREES AND SHRUBS, continued}

HYDRANGEA arborescens. Smooth Hydrangea. Upright io 100 I, 000 shrub; bright green foliage and large creamy white flowers. Attractive for large plantings.

I to 2 feet. Strong, stocky plants..............\$I 25 \$Io oo

2 to 3 feet. X strong, stocky plants.............. 2502000

paniculata. Panicle Hydrangea. Hardy, tall shrub. Creamy white flowers; dark green leaves. Splendid for mass planting or single specimens.

I to 2 feet. Strong, stocky plants.............. 650

2 to 3 feet. X strong plants.................... 8 50

60 oo 80 oo

HYPERICUM aureum. Golden St. Johnswort. Hardy shrub with bluish green leaves and large golden yellow flowers. I to $\mathrm{I} / 2$ feet. Strong plants............ I 25 I0 00

densiflorum. Common St. Johnswort. Ornamental shrub. Widely distributed. Narrow green leaves, and clusters of bright yellow flowers. Very effective.

I to 2 feet. Strong, select plants............... I 25 I0 $00 \quad 8500$

prolificum. Shrubby St. Johnswort. Vigorous, hardy shrub. Compact branches, with dark green leaves. Flowers bright yellow, in terminal clusters in late summer. I to 2 feet. Strong plants.............. I

ILEX monticola. Mountain Winterberry. Deciduous small tree, with spreading branches. Bright green leaves and scarlet berries in autumn.

6 to 12 inches. Strong, stocky plants........... I 50

I to 2 feet. X strong, stocky plants............. I 75

2 to 3 feet. XX strong, stocky plants................. 350

3 to 4 feet. XXX strong, stocky plants.... Each $75 \mathrm{c} .6$ oo

MAGNOLIA acuminata. Cucumber Tree. Pyramidal tree. Spreading branches, with bright green leaves. Greenish yellow flowers in early summer, producing rosy red cucumber fruit in early fall.

5 to 6 feet. Strong trees............... Each $\$$ I . 750

Fraseri. Fraser Magnolia. Handsome, spreading tree. Flowers large, creamy white, and very sweet-scented. Hardy tree of unusual merit, bearing large cucumber fruit. 4 to 6 feet. Strong, select trees..... Each $\$$ I . . 8 oo 


\section{HARDY DECIDUOUS TREES AND SHRUBS, continued}

OXYDENDRUM arboreum. Sourwood. Handsome hardy tree ro 100 that succeeds well under varied conditions. Beautiful autumn coloring of foliage.

6 to 12 inches. Strong, stocky plants............ \$I 25 \$10 oo

I to 2 feet. Strong, stocky, nur.-grown........... $250 \quad 20$ oo

2 to 3 feet. Strong, stocky, nur.-grown... Each $\$ 0.65 \ldots 450$ 40 oo

3 to 4 feet. Strong, stocky, nur.-grown... Each .80.. 650 60 oo

4 to 6 feet. Strong, stocky, nur.-grown....Each I.oo. . 850 80 oo

6 to 8 feet. Strong, select specimens...... Each I.50.. I3 50

ROBINIA hispida. Rose-Acacia. Drooping, rose-colored flowers in early spring. Splendid shrub for rock-garden and shrubbery border. I to 2 feet. Strong plants... 250

RUBUS odoratus. Flowering Raspberry. Vigorous, upright shrub. Leaves large, resembling the maple. Flowers rose-purple; berries light red, edible.

6 to $\mathbf{I} 2$ inches. Strong plants.............. I 50

I to 2 feet. Strong plants................. 2 oo

SAMBUCUS pubens. Scarlet Elder. Shrub with warty branches and red pith. Large, white flowers in late spring; large red berries in clusters.

I to 2 feet. Heavy select plants............. 2 oo

A Vanhouttei. Desirable native shrub. Free bloomer; large white flowers.

2 to 3 feet. Heavy, clumpy plants...... Each $85 \mathrm{cts} . .750$

VACCINIUM pallidum. Blue Ridge Blueberry. Best of all Blueberries and a desirable ornamental shrub.

I to 2 feet. Select, stocky plants........... 5 oo

2 to 3 feet. Select, stocky clumps.............. 750

3 to 4 feet. Select, stocky clumps.......... Each \$1 . 9 oo

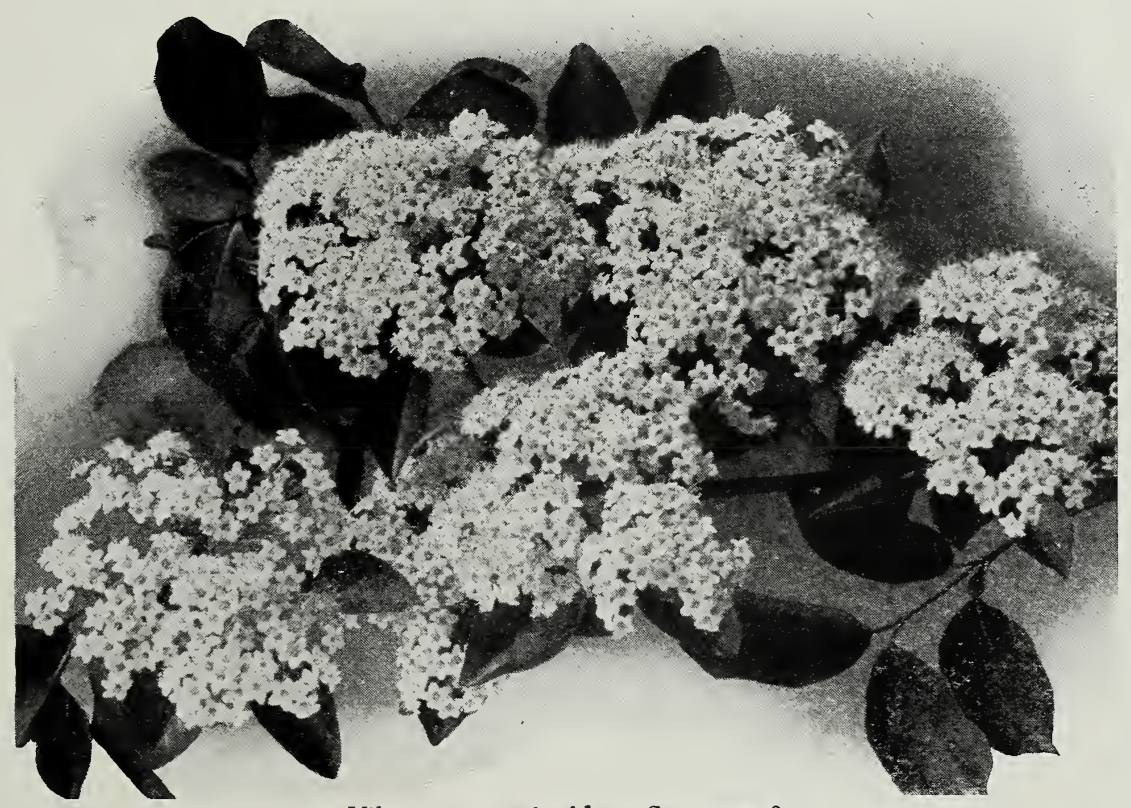

Viburnum cassinoides. See page 8 


\section{HARDY DECIDUOUS TREES AND SHRUBS, continued}

VIBURNUM cassinoides. Withe-Rod. Very hardy flowering io 100 shrub. Widely distributed. The oval, green leaves color beautifully in autumn. Flowers creamy white; berries pink to black. Desirable for planting along streams and in shrubbery border.

I to 2 feet. Heavy stocky clumps, with several stems. $\$ 6$ oo $\$ 50$ oo

2 to 3 feet. Heavy stocky clumps, with several stems. 8 oo 75 oo

3 to 4 feet. Heavy stocky clumps, with several stems. .

$$
\text { Each } \$ 1.25 \ldots \text { 10 oo } 90 \text { oo }
$$

ZANTHORHIZA apiifolia. Yellowroot. Low shrub. Beautiful

golden foliage in autumn. Very desirable for ground-

cover and thrives in variable soil conditions.

3 to 6 inches. Strong transplants.............. I oo $750 \quad \$ 60$ oo

6 to 12 inches. Strong transplants.............. I 50 Io

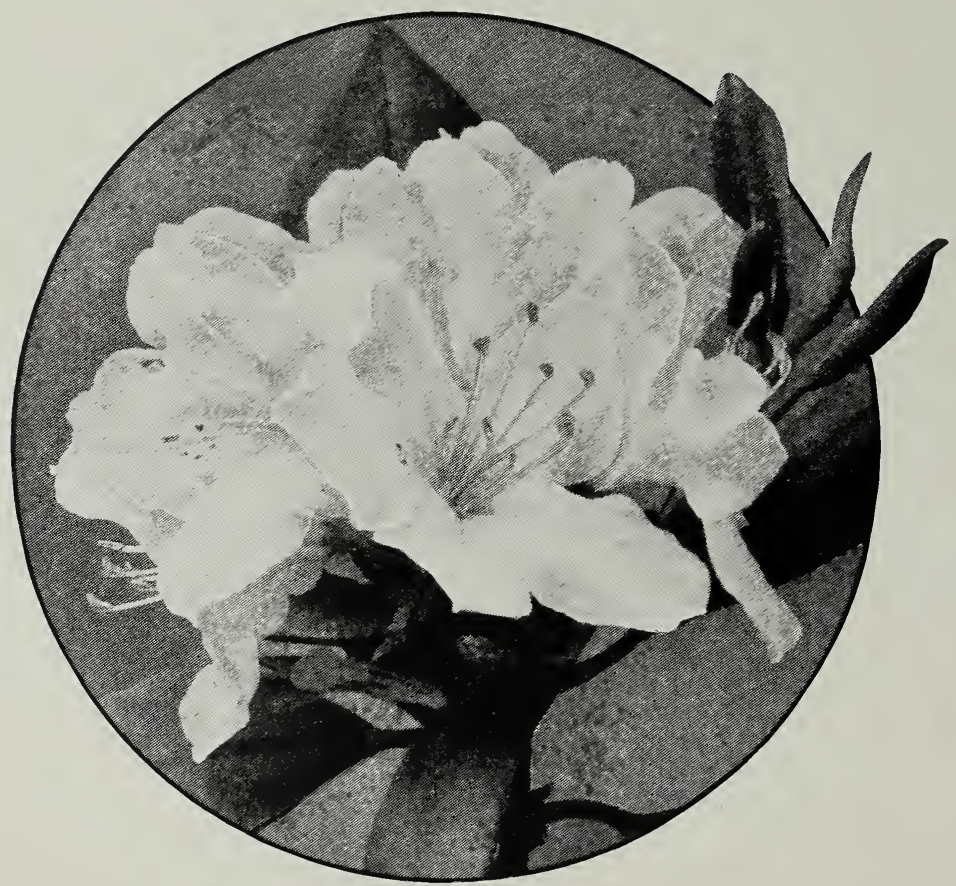

Rhododendron carolinianum. See page I 2

\section{Hardy Native Evergreen Trees and Shrubs}

ABIES Fraseri. Fraser Fir. Southern species. Very hand- io I00 I,000 some tree and extremely hardy. Foliage fragrant, dark green.

3 to 6 inches. Strong plants.............\$I oo

6 to 12 inches. Strong plants............... 2 oo

ANDROMEDA polifolia. Bog Rosemary. Small, desirable evergreen shrub for border planting.

4 to 6 inches. Strong, established plants......... 4 oo 35 oo

BUXUS sempervirens. Common Box. Large, dense shrubs. Very symmetrical.

6 to 8 in. Compact plants, balled and burlaped .......6 65060 


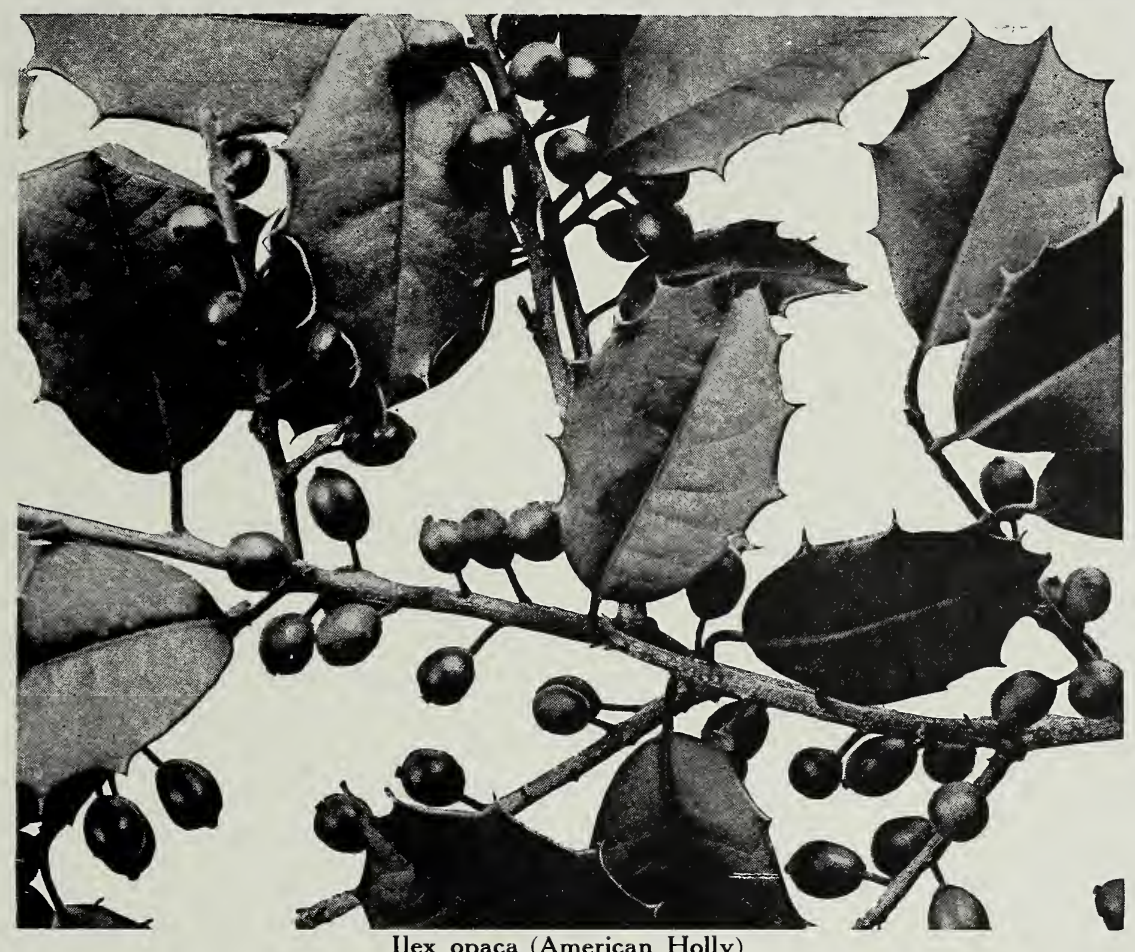

Ilex opaca (American Holly)

HARDY NATIVE EVERGREEN TREES AND SHRUBS, continued

ILEX glabra. Inkberry. Upright, well-branched shrub. Each io Ioo I,000

Leaves dark, shining, retained throughout the winter. Berries black.

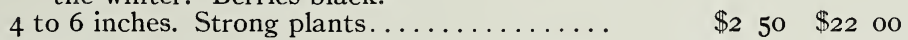

opaca. American Holly. A handsome, broadleaved evergreen, known to many as "Christmas Holly," and much used for holiday decorations. Easy of culture and adapts itself to varied soil conditions. We are well stocked on this.

4 to 6 inches. Heavy transplanted...........

6 to 12 inches. Heavy transplanted...............

I 2 to $\mathrm{I} 8$ inches. X strong trans. bl'd. and bur....

I $50 \quad$ I $250 \quad \$ 100$ OO

$250 \quad 2200 \quad 20000$

$450 \quad 40$ oo 350 oo

KALMIA latifolia. Mountain Laurel. This matchless Laurel is, without question, one of the most beautiful and attractive of the broad-leaved evergreen shrubs on account of its dark green, lustrous foliage and masses of glorious pink or rose-colored flowers, appearing in lavish profusion in late spring and early summer. Our stock is equal to the demand. We are able to make prompt shipment in scason.

4 to 6 inches. Strong transplanted........... 6 to 12 inches. Extra-heavy trans. stocky plants

9 to $\mathrm{I} 2$ inches. XXX heavy specimen clumps...\$I 25 Io $00 \quad 90$ oo 


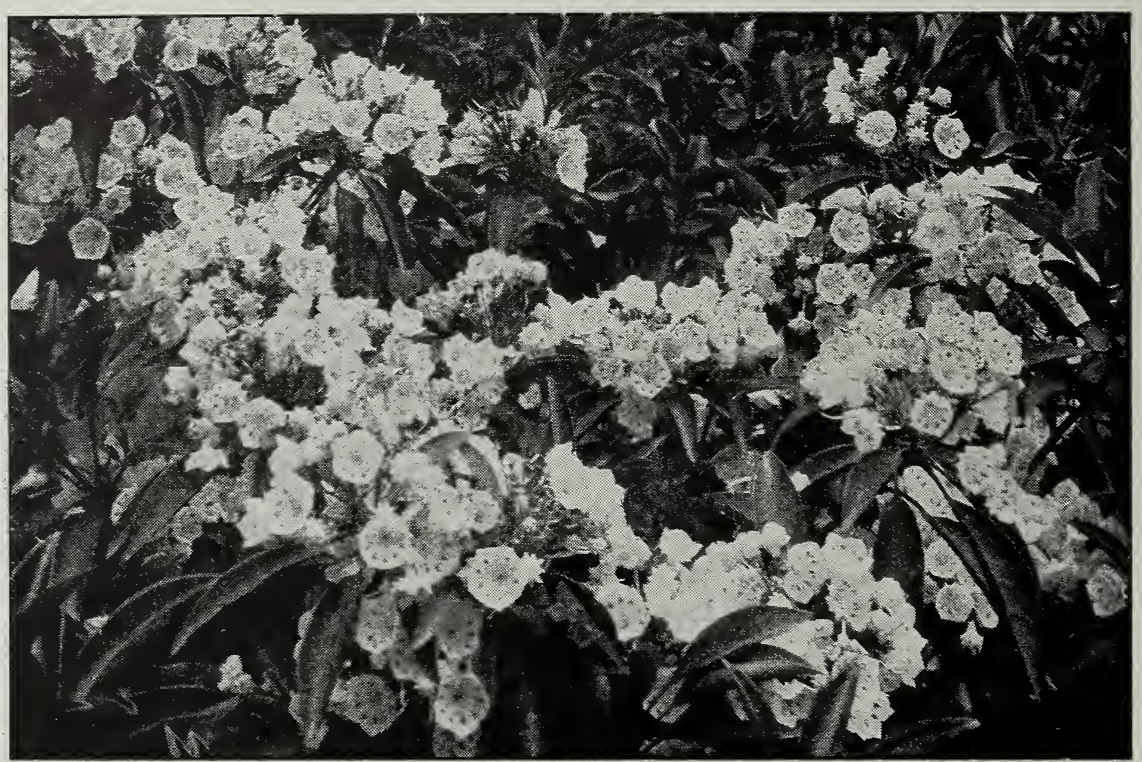

Kalmia latifolia

HARDY NATIVE EVERGREEN TREES AND SHRUBS, continued

I to 2 feet. XXX heavy specimen clumps......\$2 oo \$I 750 \$160 oo

2 to 3 feet. XXX heavy specimen clumps..... $3 \begin{array}{llllll}3 & \text { oo } & 27 & 50 & 260 & \text { oo }\end{array}$

3 to 4 feet. XXX heavy specimen clumps..... 4 oo $37 \quad 50 \quad 365$ oo

4 to 5 feet. XXX heavy-specimen clumps..... 5 oo 45 oo 400 oo

One-year heavy transplanted cut-back clumps

for growing on................... I 25 Io oo 85 oo $\$ 800$ o0

NOTE: Carload orders our specialty. Special prices promptly furnished on large requirements according to quantities taken. Our facilities for collecting this item are unequaled, although we always recommend nursery-grown material for best results. Let us figure on your requirements for above and larger sizes.

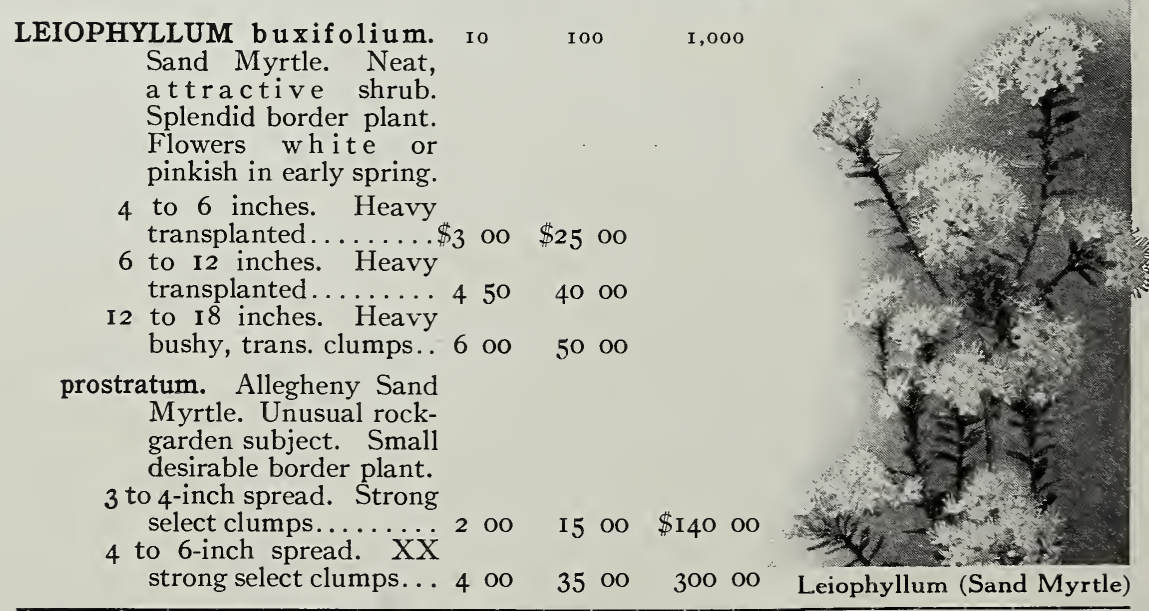




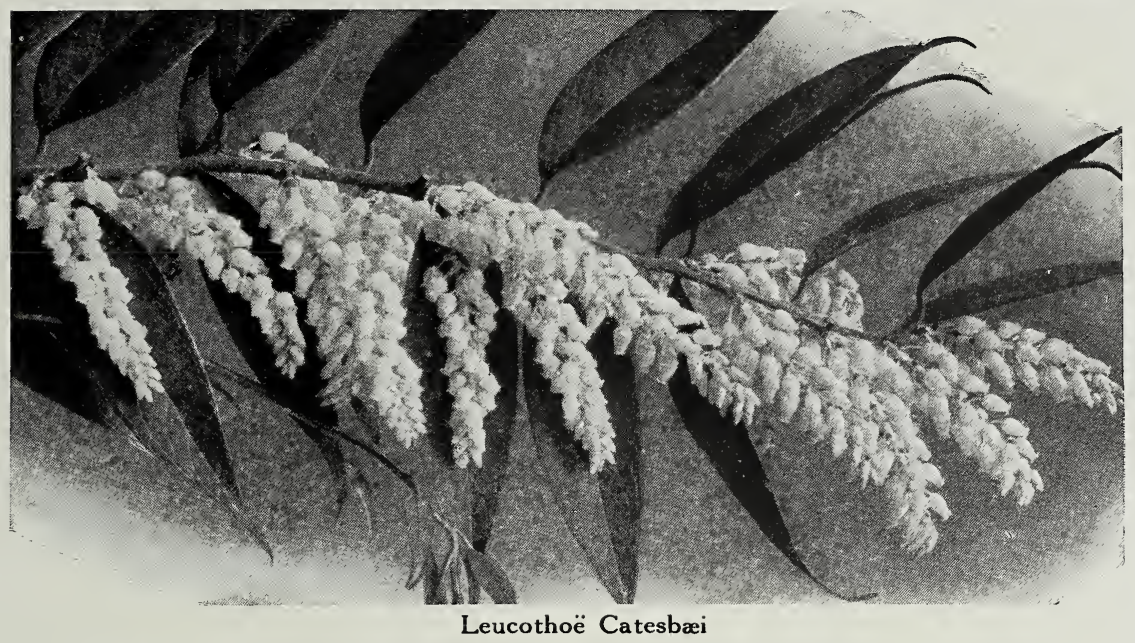

HARDY NATIVE EVERGREEN TREES AND SHRUBS, continued

LEUCOTHOË Catesbæi. Drooping Leucothoë. Hardy, то 100 r,000 graceful shrub of wide distribution. Very ornamental and much used for florist's trade. Flowers fragrant, showy, creamy white. Too much cannot be said in favor of this wonderful shrub.

4 to 6 inches. $X$ strong transplanted...........\$2 oo 6 to 12 inches. XX strong trans., stocky clumps...... 8 oo I to 2 feet. XXX strong trans., stocky clumps....... I2 oo One-year heavy trans. cut-back clumps.......... 9 oo

$\$ 17$ o0 \$150 00 70 oo 650 oo I 10 o0 1000 00

$8000 \quad 75000$

PICEA mariana. Black Spruce. Medium-sized tree. Foliage dark bluish green. Very ornamental.

9 to 12 inches. Strong transplanted.............. 3 oo 2500

I to 2 feet. Heavy trans., balled and burlaped........ 5 oo 45 oo

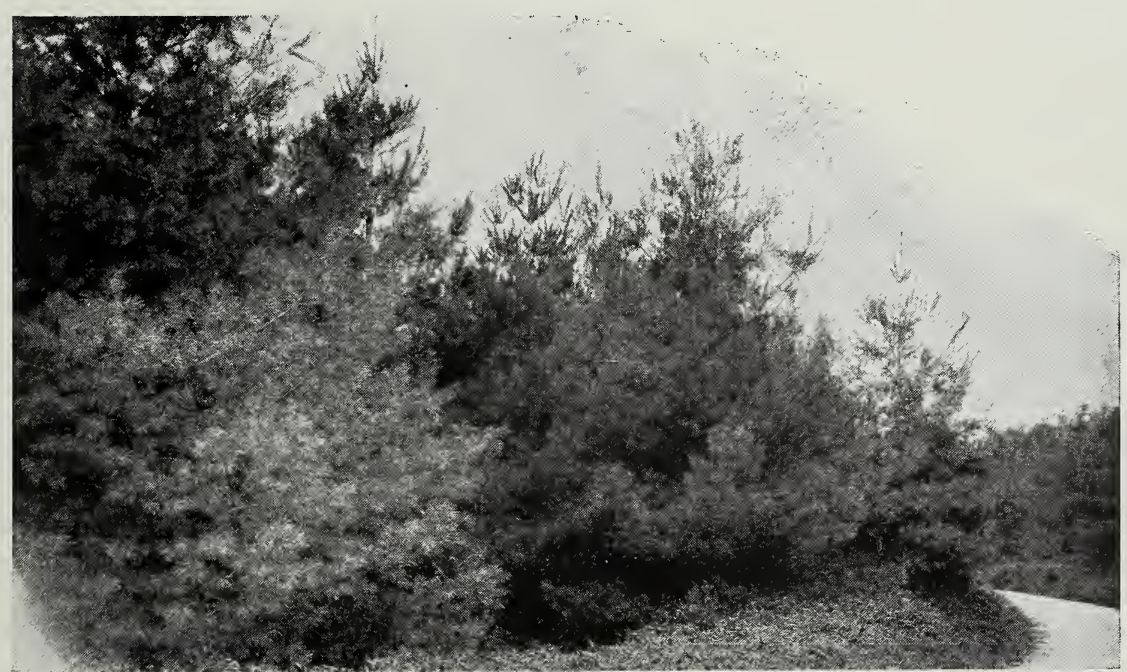

Pinus Strobus (White Pine). See page I2 


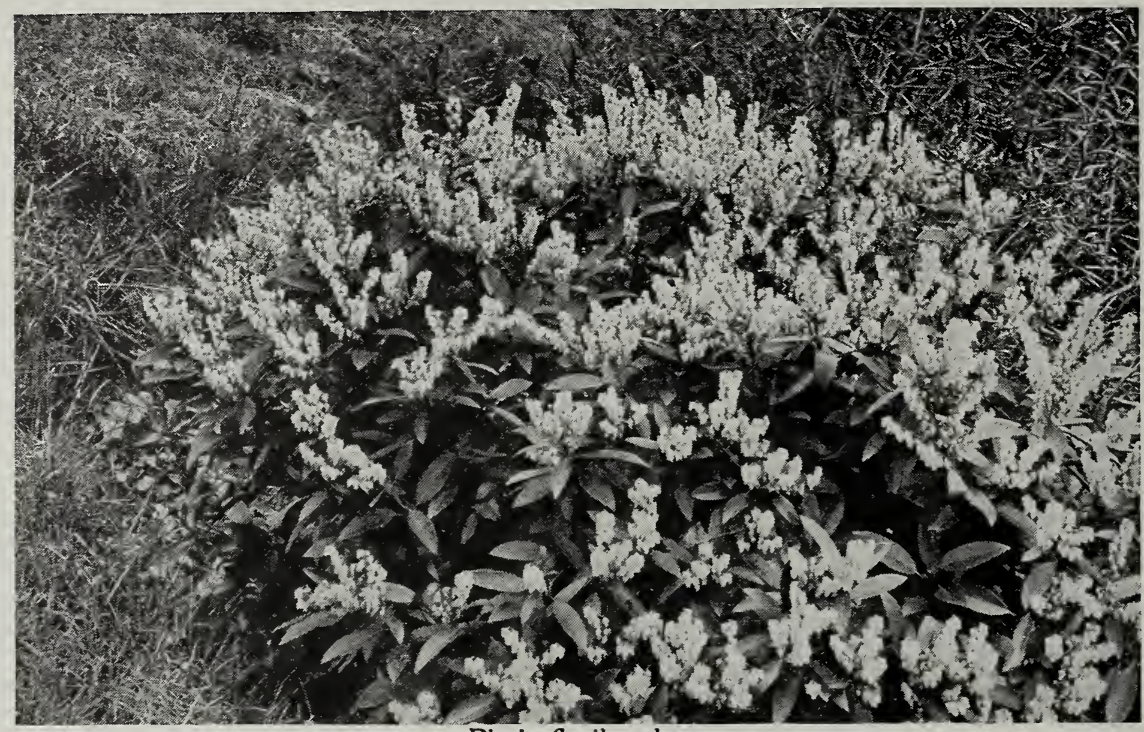

Pieris floribunda

HARDY NATIVE EVERGREEN TREES AND SHRUBS, continued

PIERIS floribunda. Mountain Andromeda. Extremely hardy io roo 1,000

ornamental evergreen, and a gem for any planting.

Showy flowers produced in clusters in early spring and lasting a long time.

6 to 12 inches. Heavy transplanted clumps........\$20 oo \$190 oo \$1850 oo I 2 to 18 inches. Heavy transplanted clump s.........

Each $\$ 3.25 \cdots 30$ o0 275 o0 2600 oo

NOTE: This is one of our specialties. Our source for collecting this item is the best to be found. Special offer in solid carload in I 2 to I 8-inch size. Very best clumps balled and burlaped. 75 cts. each for carload shipment. Estimated number to carload about 2,00o clumps. Let us figure on your requirements.

PINUS flexilis. Limber Pine. Western species. Very Each to Ioo I,000 desirable evergreen tree.

9 to 12 inches. Trans., balled and burlaped..... \$Io oo I to 2 feet. Trans., balled and burlaped........ $\quad$ I5 00

Strobus. White Pine. Best-known American evergreen tree. Tall and most beautiful.

4 to 6 inches. Strong nursery-grown seedlings..

6 to 12 inches. Strong transplanted...........

I to 2 feet. Strong trans., balled and burlaped...

2 to 3 feet. Strong trans., balled and burlaped....

3 to 4 feet. Strong trans., balled and burlaped... \$2 oo

5 to 6 feet. Strong trans., balled and burlaped... 3 oo

6 to 8 feet. Strong trans., balled and burlaped... 5 oo

RHODODENDRON carolinianum. Carolina Rhodo-

dendron. An early, free bloomer, with light

to deep pink flowers. A distinct hardy species from Piedmont section of the southern Alleghany Mountains and the earliest

flowering native Rhododendron.

4 to 6 inches. Strong, nursery-grown seedlings. .

6 to 9 inches. Strong transplanted............

9 to $\mathrm{I} 8$ inches. Strong transplanted............

I 8 to 24 inches. Strong transplanted........... 225

2 to 3 feet. XX strong transplanted clumps.... 350

3 to 4 feet. XX strong transplanted clumps.... 5 oo

One-year heavy cut-back trans. clumps........

\begin{tabular}{|c|c|c|}
\hline 0 & & $\$ 5$ \\
\hline & 50 & \\
\hline 20 & b & 100 \\
\hline 50 & & I 40 \\
\hline 185 & 50 & 175 \\
\hline & & 240 \\
\hline & & 425 \\
\hline
\end{tabular}

$\$ 27 \quad 50$

$\begin{array}{rrrr}2 & 50 & 20 & 00 \\ 4 & 00 & 35 & 00 \\ 17 & 50 & 150 & 00 \\ 20 & 00 & 185 & 00 \\ 30 & 00 & 280 & 00 \\ 45 & 00 & 425 & 00 \\ 8 & 00 & 75 & 00\end{array}$

I 8500

65000 


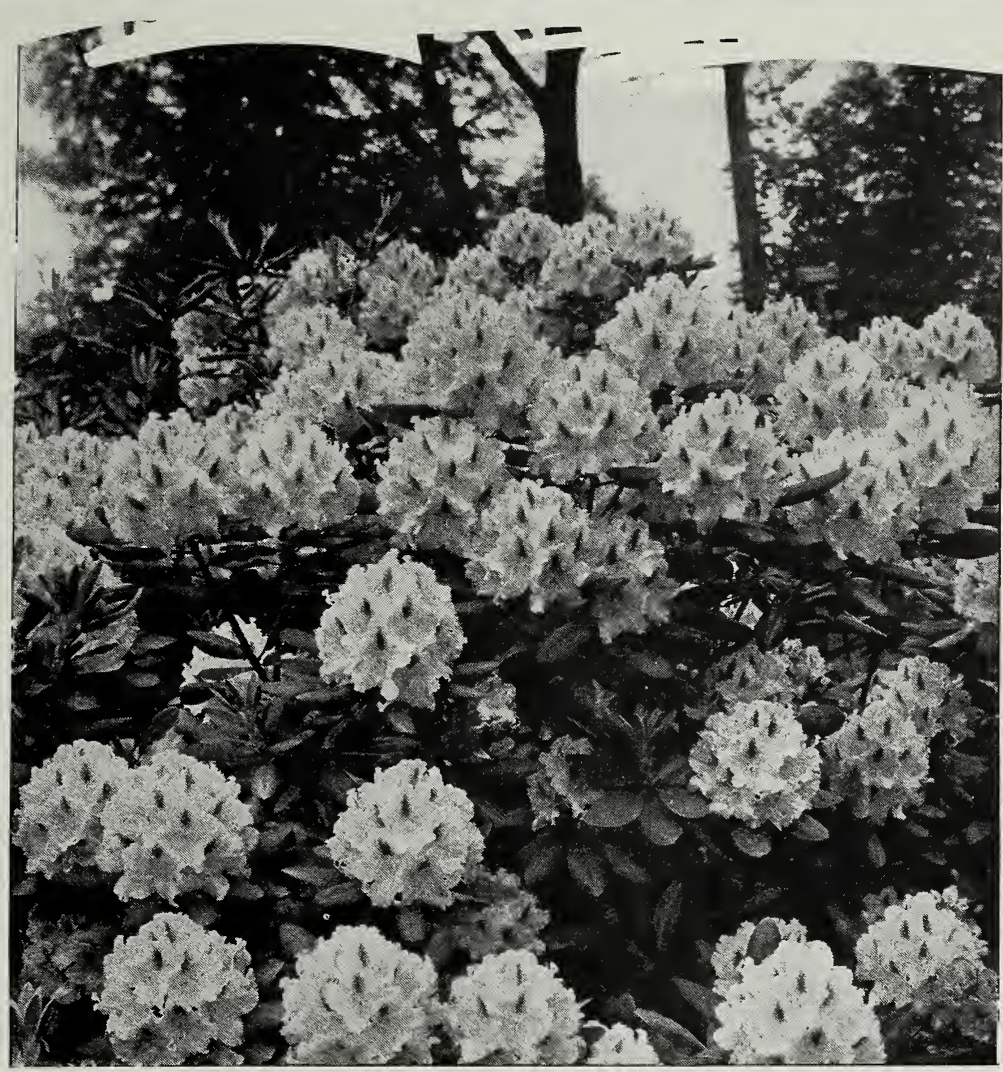

Rhododendron catawbiense

HARDY NATIVE EVERGREEN TREES AND SHRUBS, continued

Rhododendron carolinianum album. White Carolina Rhododendron, from Piedmont section. Dwarf, early-blooming variety. Rare and most beautiful.

4 to 6 inches. Transplanted..............

catawbiense. Catawba Rhododendron. Most vigorous, hardy, free-blooming variety, with gorgeous display of rosy purple flowers in early summer. Foliage dark green and exceedingly showy. Hardiest of all Rhododendrons. We have the largest stock in existence of this variety.

Special price on carload orders.

4 to 6 inches. Strong transplanted..........

6 to 12 inches. Strong trans., stocky plants...

9 to 12 inches. XX strong trans., stocky cl....\$ \$ 75

I to 2 feet. XX strong trans., stocky cl...... 275

2 to 3 feet. Strong established clumps........ 4 oo

3 to 4 feet. Strong established clumps....... 5 oo

4 to 5 feet. X strong established clumps...... 650

5 to 6 feet. XX specimen clumps.......... 9 oo

One-year strong cut-back trans. clumps........

Io

100

$\mathrm{I}, 000$

NOTE: Let us figure on your requirements in carload shipments.

$\begin{array}{rrrrrr}3 & 50 & 30 & 00 & \$ 275 & 00 \\ 5 & 00 & 45 & 00 & 400 & 00 \\ 15 & 00 & 140 & 00 & 1300 & 00 \\ 25 & 00 & 235 & 00 & & \\ 35 & 00 & 325 & 00 & & \\ 40 & 00 & 375 & 00 & & \\ 60 & 00 & 500 & 00 & & \\ 85 & 00 & 800 & 00 & & \\ 12 & 00 & 100 & 00 & 900 & 00\end{array}$




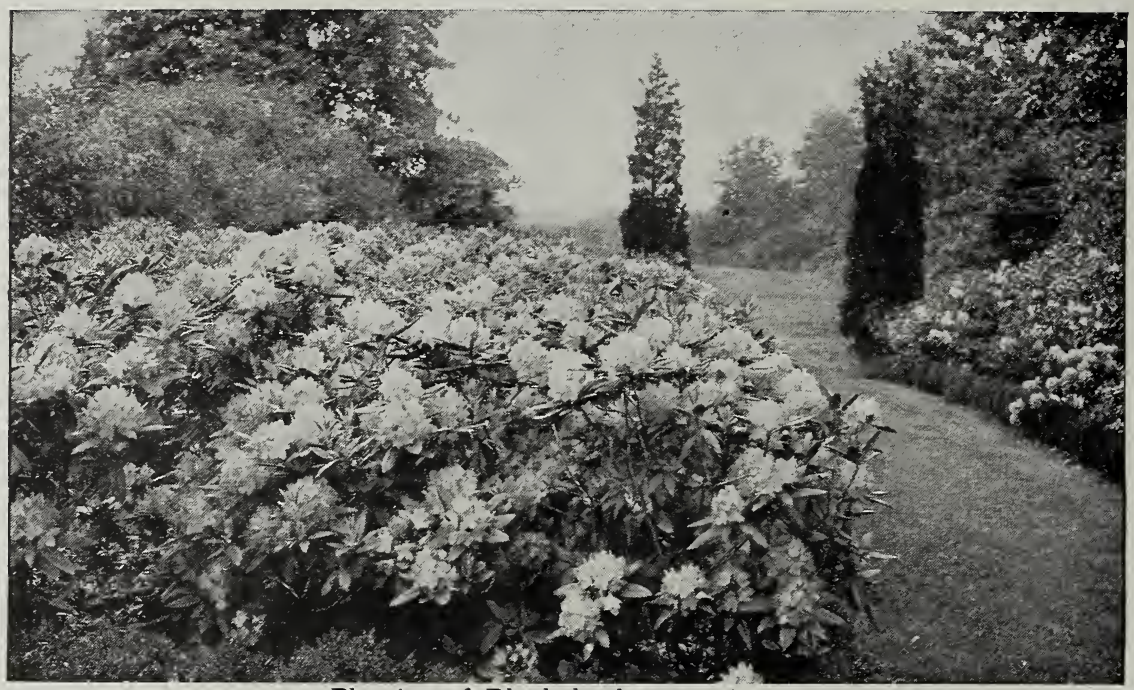

Planting of Rhododendron maximum

HARDY NATIVE EVERGREEN TREES AND SHRUBS, continued

Rhododendron maximum. Rosebay. This is the Each ro 100 I,000 grandest species and most used for massing and naturalistic planting of all native broadleaved evergreens. Flowers pinkish white in large clusters in July. We are prepared to supply splendid plants in all sizes. Special quotations for carload shipments. Send in your list of requirements early to allow best opportunity of serving.

4 to 6 inches. Strong transplanted..........

6 to 12 inches. Strong transplanted...........

9 to 12 inches. XX heavy transplanted clumps $\$$ I 50

I to 2 feet. XXX heavy transplanted clumps... 250

2 to 3 feet. XXX heavy transplanted clumps... 350

3 to 4 feet. XXX heavy transplanted clumps... 5 oo

NOTE: Very special prices promptly quoted for carload shipments. Let us figure on your requirements.

TSUGA canadensis. Canada Hemlock. Tall, graceful Each tree with spreading branches. Beautiful tree for park or landscape. One of our best hedge products and becoming more popular for general planting.

9 to 12 inches. Strong transplanted..........

I to 2 feet. Strong trans., balled and burlaped...

2 to 3 feet. Strong trans., balled and burlaped.. \$3 50

3 to 4 feet. Strong trans., balled and burlaped.. 5 oo

4 to 5 feet. Strong trans., balled and burlaped.. 650

5 to 6 feet. Strong trans., balled and burlaped. . 850

6 to 7 feet. Strong trans., balled and burlaped.. 950 carolinis na. Carolina Hemlock. Queen of American evergreen trees. One of the hardiest and most desirable evergreens from the Carolina mountains.

4 to 12 inches. Strong transplanted..........

I to 2 feet. Strong trans., balled and burlaped..

2 to 3 feet. Strong trans., balled and burlaped.. 5 oo

3 to 4 feet. Strong trans., balled and burlaped.. 650

$\begin{array}{rrrrrr}\$ 2 & 00 & \$ 17 & 50 & \$ 160 & 00 \\ 3 & 00 & 25 & 00 & 220 & 00 \\ 12 & 50 & 120 & 00 & & \\ 20 & 00 & 185 & 00 & \text { I } 700 & 00 \\ 30 & 00 & 280 & 00 & & \\ 45 & 00 & 420 & 00 & & \end{array}$

4 to 5 feet. Strong trans., balled and burlaped.. 8 oo

$\$ 350 \quad \$ 30$ o0

I5 OO I35 OO

30 o0 275 o0

45 o0 425 o0

60 o0 550 o0

75 o0 650 oo

8500

$\begin{array}{rrrrrr}3 & 50 & 30 & 00 & \$ 275 & 00 \\ 25 & 00 & 200 & 00 & & \\ 45 & 00 & & & & \end{array}$




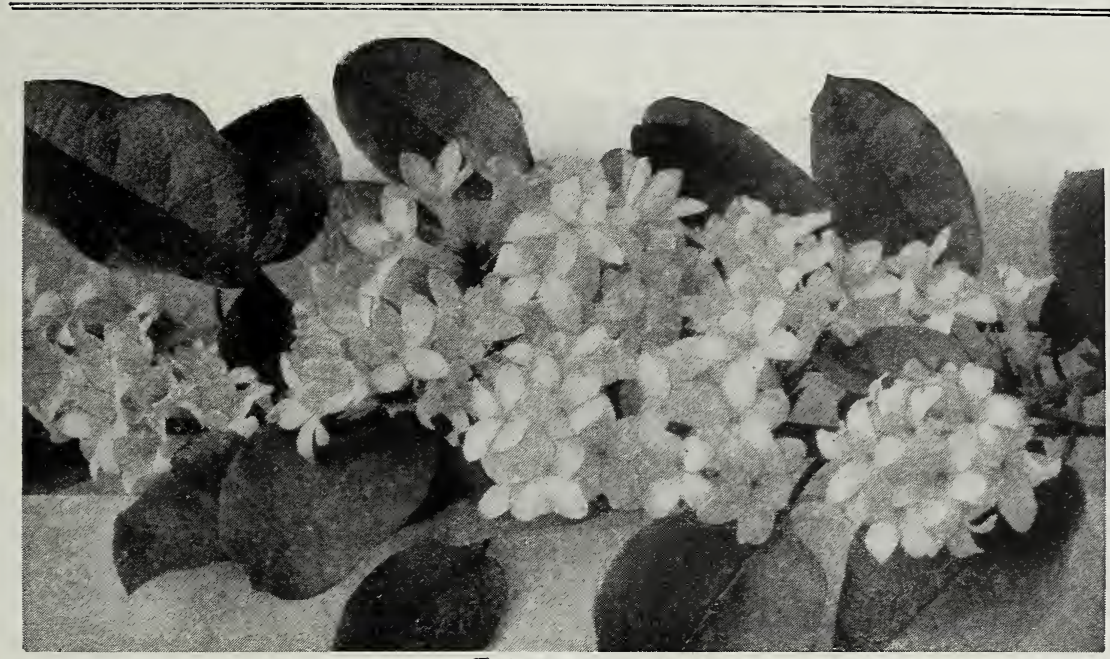

Epigæa repens

\section{Hardy Vines, Climbers, and Creepers}

AMPELOPSIS Engelmanni. Engelmann Creeper. Finest io $100 \quad 1,000$ clinging form of Virginia Creeper. A good climber, with beautifully colored foliage in autumn.

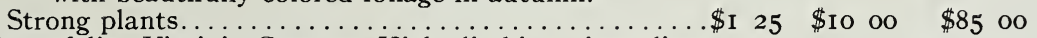

quinquefolia. Virginia Creeper. High-climbing vine, clinging to walls and trees, with beautifully colored foliage in autumn. Heavy transplanted plants.........2 2 oo 1500

CELASTRUS scandens. American Bittersweet. High-climbing vine. Very ornamental. Strong, stocky plants.... I 50 I2 50

CLEMATIS crispa. Curly Clematis. Graceful vine. Flowers purple in midsummer. Strong plants........... $300 \quad 2500$

virginiana. Virgin's Bower. Hardy climber. Very popular for general planting. X strong, stocky plants.....2 2 oo $\quad$ I7 $50 \quad$ I50 00

DIOSCOREA villosa. Yam. Showy vine with leaves turning golden yellow in autumn. Strong plants......... I 50 I2 50 100 00

EPIGEA repens. Trailing Arbutus. Charming plant, with very fragrant white or pink flowers.

Strong, stocky plants................ $250 \quad 20$ o0 17500

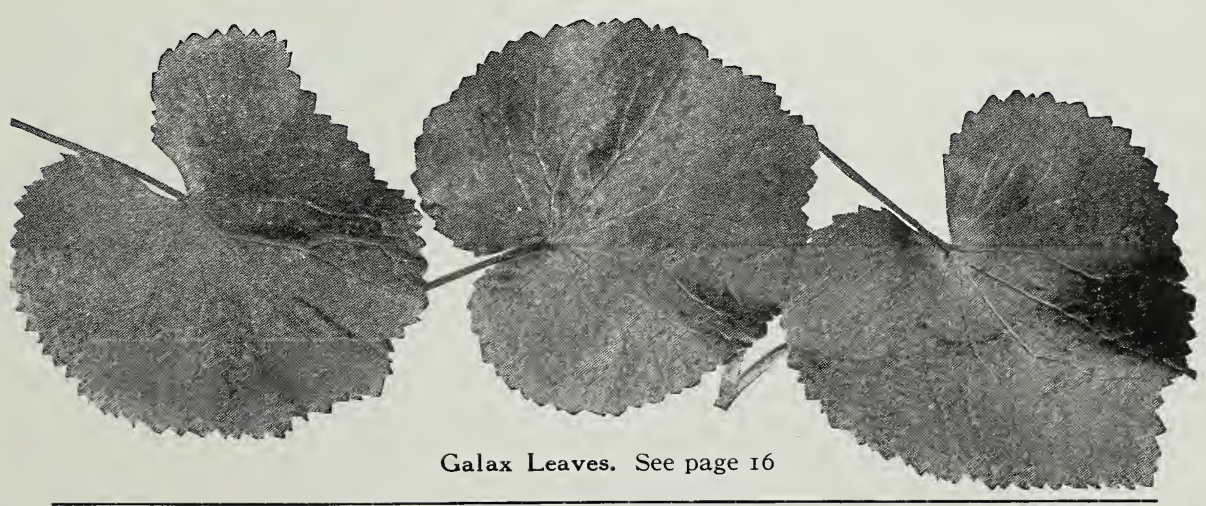

NOTE: 5 at 10 rate, 25 at 100 rate, 250 at 1,000 rate 


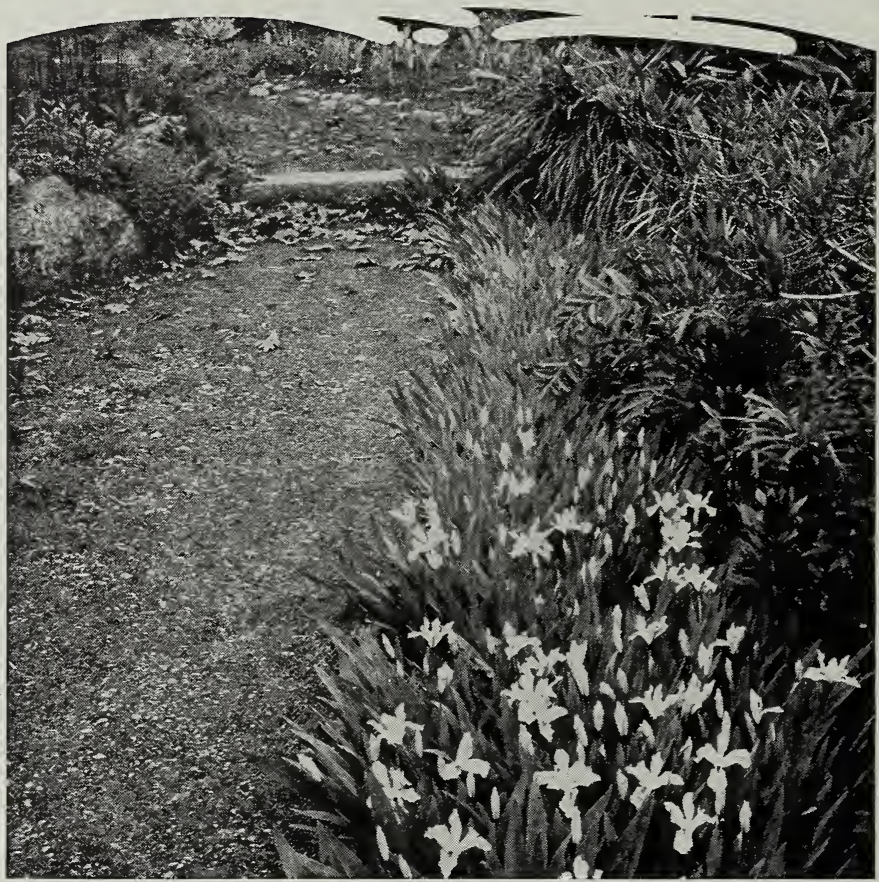

Iris cristata

HARDY VINES, CLIMBERS, AND CREEPERS, continued

GALAX aphylla. Galax. One of our best ground-cover plants I0 for shady locations. The very ornamental bronze and green leaves are much used in florist's trade.

Strong established clumps..................... $200 \quad \$ 1500 \quad \$ 12500$

GAULTHERIA procumbens. Wintergreen. Very desirable ground-cover, with brilliant green and bronze leaves. Bright red edible fruit in winter.

Strong established clumps................. I $75 \quad$ I5 $00 \quad$ I25 00

HOUSTONIA serpyllifolia. Creeping Bluets. Early white and blue flowers. Very ornamental for rockery and along streams. Strong established clumps............. I 75 I5 $00 \quad$ I25 00

IRIS cristata. Crested Iris. Splendid ground-cover for shady or open locations. Leaves green. Flowers blue.

$\mathrm{X}$ strong established clumps.................. I 50 I2 $50 \quad 10000$

germanica. German Iris. Vigorous growing species with large, showy flowers of assorted colors.

$\mathrm{X}$ strong established plants.................. $350 \quad 3000$

verna. Vernal Iris. Blue flowers. Splendid ground-cover.

Strong clumpy plants..................... I $75 \quad$ I5 $00 \quad$ I25 00

LONICERA japonica Halliana. Hall's Honeysuckle. Very strong-growing vine. Fragrant white and yellow flowers in summer and autumn. Best for trellises and ground-cover. Strong plants............ I 50

Light plants for lining out.................. I oo

$1250 \quad 10000$

$750 \quad 6500$

MITCHELLA repens. Partridge Berry. A splendid evergreen ground-cover best suited to shady places. Flowers white or purple tinged. Berries bright red in winter.

Strong clumps.......................... I $75 \quad$ I5 $00 \quad$ I25 00 
HARDY VINES, CLIMBERS, AND CREEPERS, continued

PHLOX stolonifera ( $P$. reptans). Creeping Phlox. Free-growing ground-cover. Flowers reddish purple in early spring. Strong clumps.....................

subulata. Moss Pink. Evergreen ground-cover. Good for
rockery and border planting. Flowers vary from white to pink, purple, and rose. Strong plants..... 2 oo $\quad$ I7 $55^{0} \quad$ I 50 oo

RUBUS hispidus. Swamp Dewberry. Good ground-cover. Leaves color beautifully in autumn. Strong plants... I 50 Io oo 85 oo

trivialis. Southern Dewberry. Showy flowers and fruit. Splendid ground-cover. 2 to 3 feet. Strong plants.. I 25 Io oo 8500

SEDUM telephoides. Wild Liveforever. Fleshy leaves and flowers. Suitable for rockery and other dry situations. Strong plants................... $250 \quad 2000$

ternatum. Mountain Stonecrop. Handsome creeping ground-cover with white flowers in early spring. Widely distributed. Strong clumps.............

SHORTIA galacifolia. Oconee Bells. Beautiful shade-loving evergreen ground-cover. Flowers nodding, pink and white, in very early spring.

Light established plants................. I 75 I5 oo 100 oo

$\mathrm{X}$ strong established, clumpy plants............ 2 50 20 oo $\quad$ I 75 oo

\section{Hardy Native Ferns}

For shady locations, no class of plants can equal the Ferns. They are easily grown in ordinary soils and will thrive where it is often impossible to make flowering plants succeed. We handle large quantities of Ferns annually and recommend the following:

ADIANTUM pedatum. American Maidenhair Fern. Decidu- to 100 I,000 ous. One of the most distinct and beautiful.

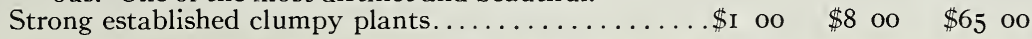

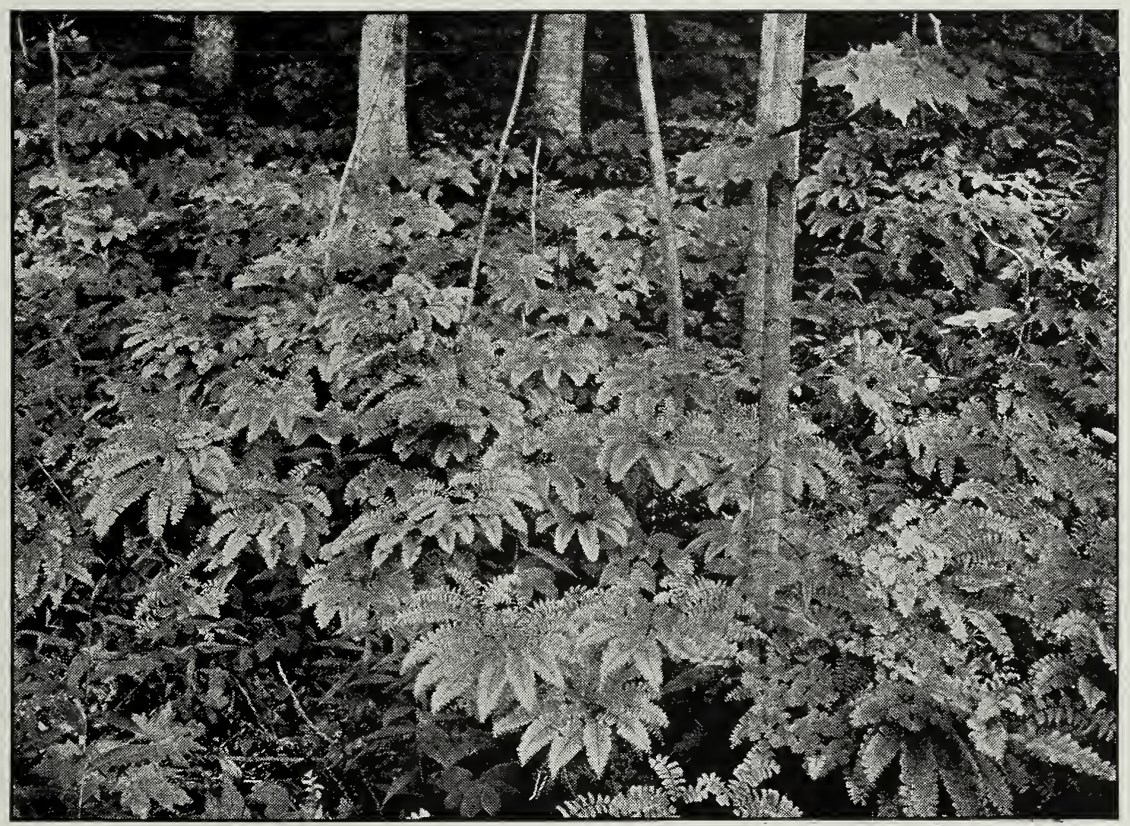

Adiantum pedatum 


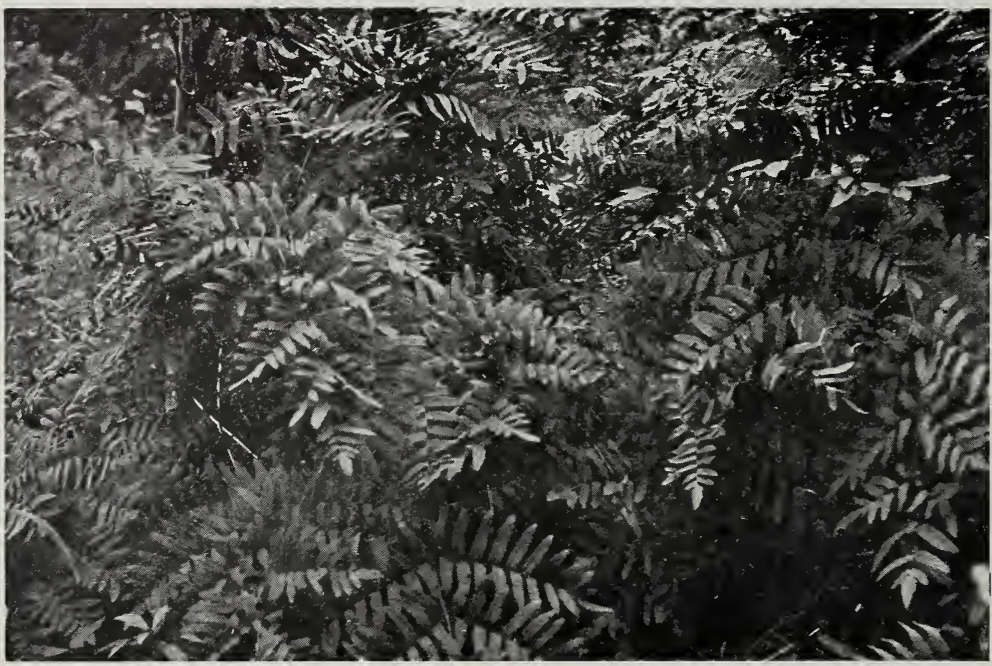

Osmunda regalis. See page is

\section{HARDY NATIVE FERNS, continued}

ATHYRIUM Filix-fœmina. Lady Fern. Large; deciduous; I exceedingly showy.

$\mathrm{X}$ strong established plants.................\$I $25 \quad \S_{\text {Io }}$ oo $\$ \$ 7500$

BOTRYCHIUM virginianum. Rattlesnake Fern. Deciduous.

Triangular fronds, deeply cut. Showy.

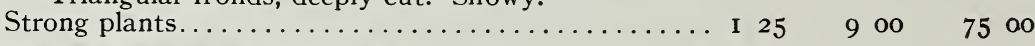

CYSTOPTERIS bulbifera. Berry Bladder Fern. Deciduous. Narrow, slender, delicate species, with bulblets on ends of fronds. Strong plants.............2

DICKSONIA punctilobula. Hay-scented Fern. A very handsome, vigorous-growing deciduous species. Recommended for shade or open situations. Widely distributed. X strong clumps................. I oo 6 oo 50 o

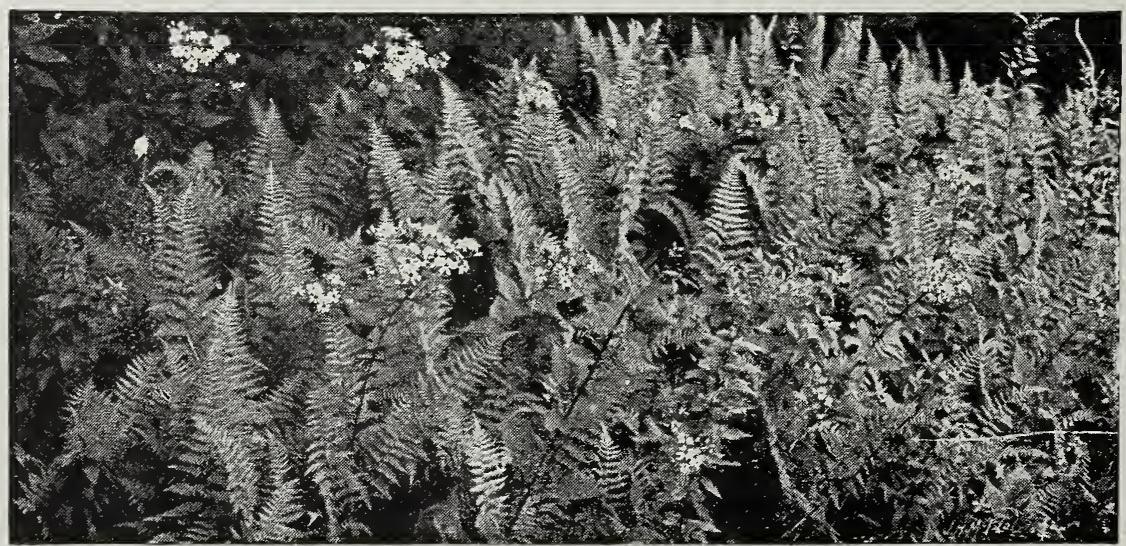

Dicksonia punctilobula 


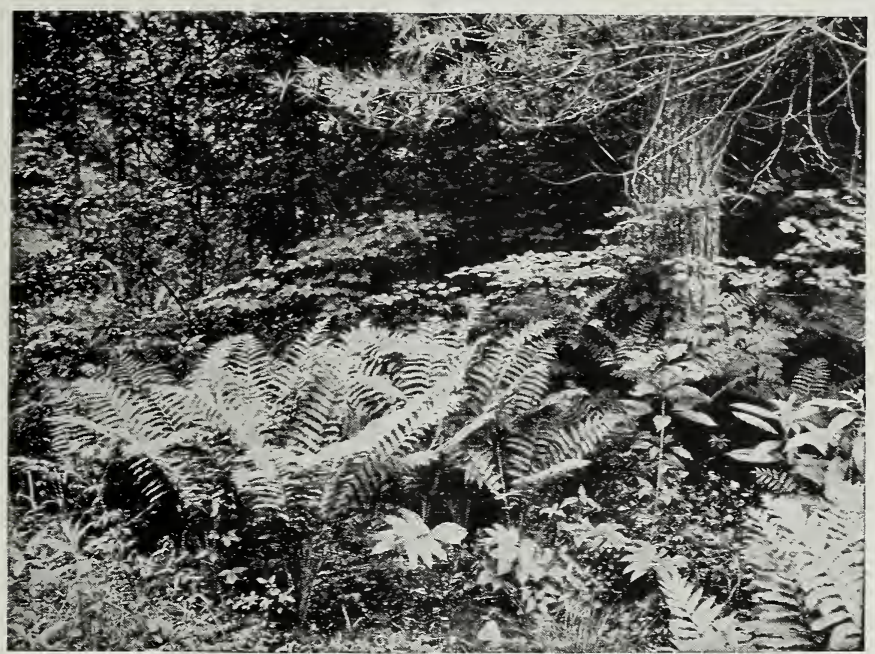

Osmunda cinnamomea

HARDY NATIVE FERNS, continued

DRYOPTERIS hexagonoptera. Winged Woodfern. Decidu- io ous. Broad, triangular fronds. Strong plants......\$I 25 marginalis. Leather Wood Fern. Robust, evergreen, showy species. X strong plants................. I oo 9 oo 7500 spinulosa. Toothed Wood Fern. Evergreen.

$\mathrm{X}$ strong plants...................... I oo $85^{0} \quad 700$

ONOCLEA sensibilis. Sensitive Fern. Deciduous. Suitable for dry or moist locations.

Strong established plants................. I 25 Io 00

OSMUNDA cinnamomea. Cinnamon Fern. A stately, very large, deciduous grower. XX strong established..... I 25 Io oo 8500

claytoniana. Interrupted Fern. Deciduous. Very bold, attractive species. XX strong established........... I 25 Io oo 8500

regalis. Royal Fern. Large; deciduous, bearing attractive foliage. X strong established plants............ I 25 Io $00 \quad 8500$

POLYPODIUM vulgare. Common Polypody. A charming little evergreen Fern. Excellent for rockery.

Strong clumpy plants..................... I $25 \quad 9$ oo 75 oo

POLYSTICHUM acrostichoides. Christmas Fern. Evergreen and extremely ornamental. Much used for florists' trade. X strong established................. I oo $850 \quad 75$ oo

PTERETIS nodulosa. Ostrich Fern. Strong, deciduous, bold growing, of immense size.

$\mathrm{X}$ heavy established clumpy plants............ 2 o0 I7 $50 \quad$ I50 00

PTERIDIUM aquilinum. Bracken. Deciduous. Tall-growing.

Strong plants.......................... I oo 6 oo 50 oo

Home-owners and gardeners who require large quantities of plants will do well to consult with me. I specialize in Pieris floribunda, Azaleas, Rhododendrons, Kalmias, Oxydendrum, Leucothoe Catesbæi, Zanthorhiza, Trilliums, Stenanthiums, and other rare native plants. 


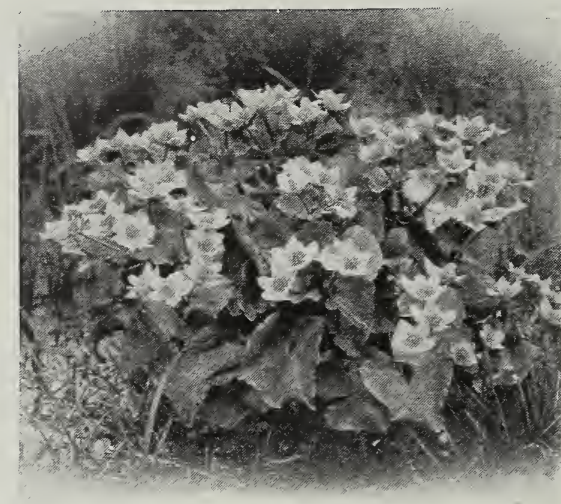

Caltha palustris

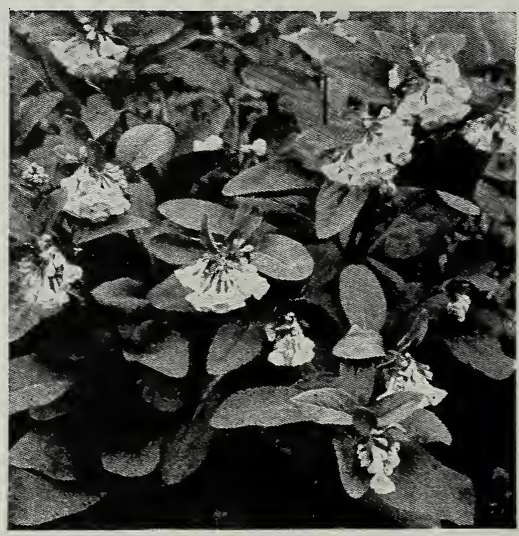

Mertensia virginica

\section{Hardy Aquatic and Bog Plants}

ACORUS Calamus. Sweet Flag. Hardy waterside plant, with ro 100 1,000 sword-shaped bright green leaves.

Strong established plants................\$I $25 \quad \$ 9$ oo $\$ 80$ oo

ASTER puniceus. Swamp Aster. Lilac-blue; tall-growing.

X strong established clumps................. I 25

BIDENS trichosperma. Ditch Sunflower. Strong plants...... I oo

9 o0 80 oo

CALTHA palustris. Marsh Marigold. Beautiful marsh plant.

Leaves bright green, heart-shaped. Flowers bright yellow, showy. Strong plants............. 2 oo

$800 \quad 7000$

CHELONE glabra. White Turtlehead. Strong grower. Flow-
ers white to rose. Suitable for dry or wet locations.

Strong plants........................ I 25

Lyoni. Pink Turtlehead. Flowers red or rose. Splendid bog-plant. Strong established plants........... I 25

CICUTA maculata. Spotted Water Hemlock. 3 to 5 feet. Cut leaves. Greenish white flowers. Strong plants..... I oo

COPTIS trifolia. Gold-thread. Free-growing, small bog-plant.

Strong plants......................... 200

900

7500

$900 \quad 7500$

850

I7 50

CORNUS canadensis. Bunchberry. Splendid ground-cover, with scarlet berries in late summer and early autumn.

Strong plants....................... 2 оо 1750

DIONAEA muscipula. Venus' Flytrap. Strange and most unusual in captivating flies and other insects for food. Rare and very interesting. Strong plants... $250 \quad 2000$

HEMEROCALLIS fulva. Tawny Day Lily. Stems 2 to 4 feet high. Flowers tawny orange. Very showy.

Strong plants..................... I 50 I2 50

IRIS pseudacorus. Yellow Flag. Stems 3 to 5 feet high. Large, sword-shaped leaves. Yellow flowers.

Heavy established plants................ I $75 \quad$ I5 00 I25-00

versicolor. Blue Flag. Height 2 to 4 feet. Suitable for border planting along ponds and streams.

Strong established plants.................. I $75 \quad$ I5 $00 \quad$ I25 00

MERTENSIA virginica. Virginia Bluebells. Height 9 to 18 inches. Green foliage and showy blue flowers.

Strong established plants.................. I $75 \quad$ I5 $00 \quad$ I25 00 


\section{HARDY AQUATIC AND BOG PLANTS, continued}

MONARDA didyma. Oswego Beebalm. Height 3 to 5 feet. ro 100 One of our most brilliant perennials. Leafy stems with bright scarlet flowers.

Strong established plants.................\$I 25 \$I0 oo

ORONTIUM aquaticum. Golden Club. Water-loving plant. Dark green foliage. Flowers club-like, golden yel-

low, in early spring. Strong plants.......... 3 oo 2500

SARRACENIA flava. Trumpet Pitcherplant. Interesting bogplant. Height I to 2 feet. Yellowish green trumpetshaped leaf. Flowers large, yellow, very conspicuous. Strong established plants............ 2 оо

purpurea. Common Pitcherplant. Hardy plant 9 to 15 inches high. Succeeds best in mossy bogs. Flowers purplish yellow. Strong established............ I $75 \quad$ I5 00

SAXIFRAGA virginiensis. Virginia Saxifrage. Height 6 to I 8 inches. Lettuce-like foliage. Flowers white. Damp locations. Strong plants............. I 50 I2 00

TYPHA latifolia. Common Cat-tail. Water-loving plant 4 to 8 feet high, widely distributed. Large green leaves. Flowers large brown spikes. Very pleasing.

Strong plants................... I 25 I0 00,70 oo

VERATRUM viride. American False Hellebore. Height 2 to 4 feet. Yellowish green plant; large leaves. Succeeds well in either dry or moist soil. Flowers greenish white in early spring.

Heavy, established, clumpy plants............ 2 oo $\quad 1750 \quad$ I50 oo

VERNONIA noveboracensis. Common Ironweed. Height 4 to 6 feet. Dark green leaves. Large purple flowers.

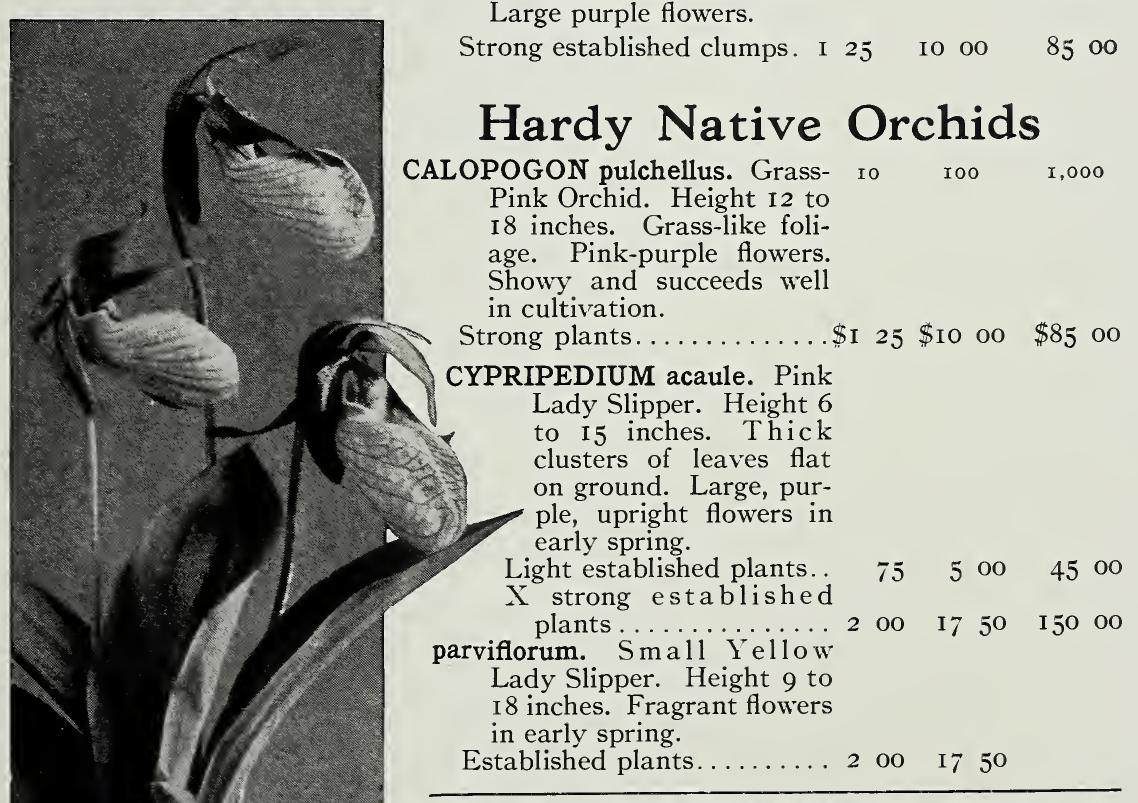

Cypripedium acaule

Note that my new address is Ashford, McDowell Co., North Carolina, on the famous scenic Clinchfield Railroad. 


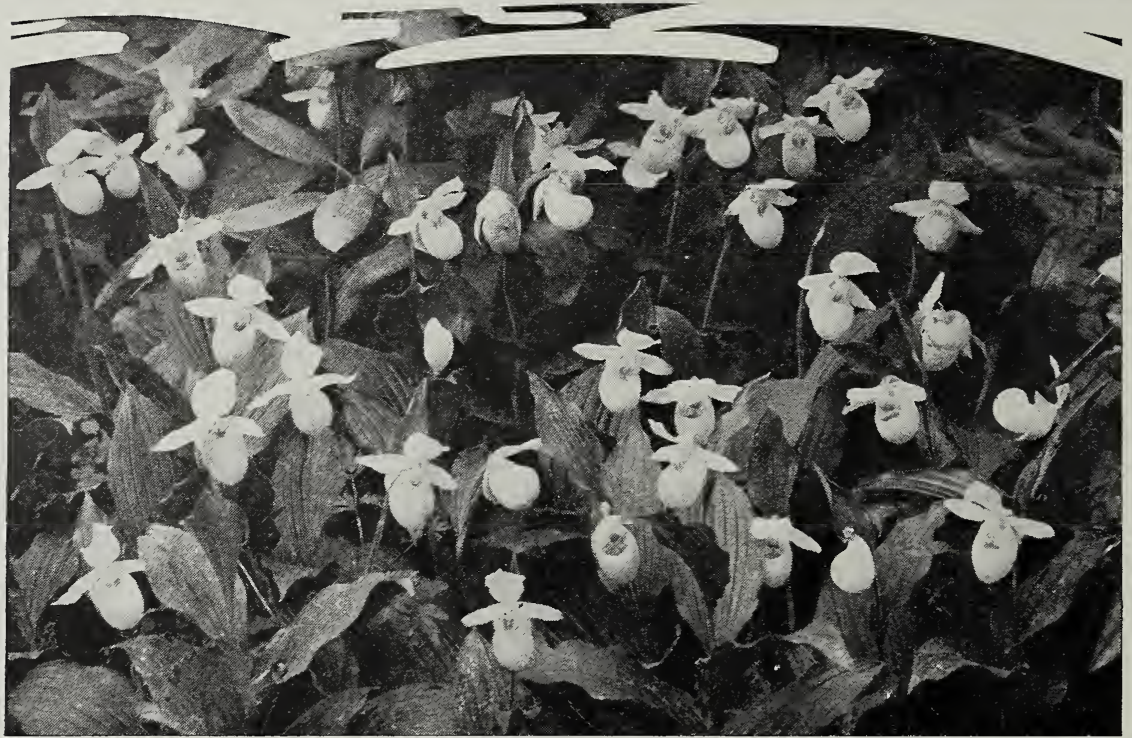

Cypripedium spectabile

\section{HARDY NATIVE ORCHIDS, continued}

Cypripedium pubescens. Common Lady Slipper. Height 12 to ro 20 inches. Flowers bright yellow in May.

Medium-size established plants..............\$I oo

$\mathrm{X}$ strong established plants................... 2 oo

roo

1,000

spectabile. Showy Lady Slipper. Height I to $21 / 2$ feet.

White to rose-color flowers in June and July.

Extra-strong grower in peat soils. By far the best of all Cypripediums. We have splendid stock of several thousand strong clumps, and shipment can be made promptly.

$\mathrm{X}$ strong, I to 3 flowering crowns to each plant....4 4 oo 35 oo 300 oo

$\mathrm{XX}$ strong, 4 to 6 flowering crowns to each clump... I 250 IOo oo 850 oo

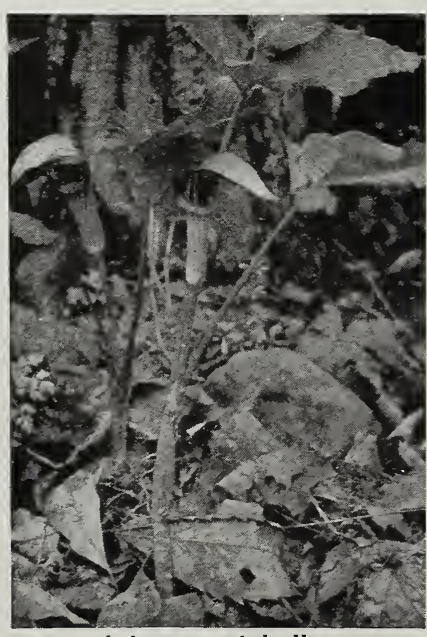

Arisæma triphyllum
HABENARIA ciliaris. Yel-

low Fringe Orchid. Height 12 to 20 in. Yellow flowers. Very handsome free bloomer. Suitable for rockery.

Strong established plants.......... I 25 I0 $00 \quad 85$ 00

psycodes. Small Purple Fringe Orchid. Height 9 to 18 in. Best suited to shade.

Strong established plants..........2 2 oo $175^{0}$

ORCHIS spectabilis. Show Orchid. Height 6 to 12 in. Flowers showy pinkpurple in early spring. Best adapted to shade. Strong established plants. . I 50 I2 50 I00 00 


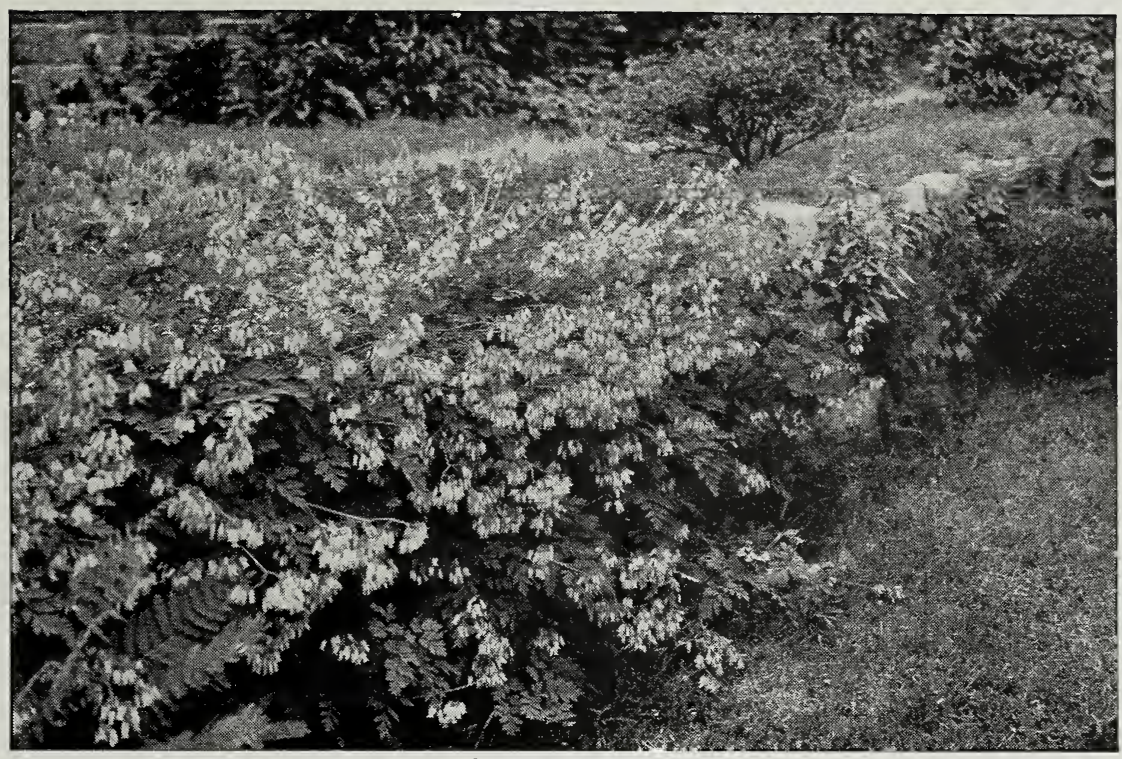

Dicentra eximia

\section{Hardy Native Lilies and Bulbous Plants}

ARIS EMA triphyllum. Jack-in-the-Pulpit. Height 2 to $21 / 2$ Io 100

I, 000 feet. Strong, fleshy top and conspicuous greenish white flowers. Light established plants.........\$0 75

$\mathrm{X}$ strong established plants.................... I 25

$\$ 6$ oo $\$ 50$ oo

IO $00 \quad 85$ OO

CONVALLARIA majalis. Lily-of-the-Valley. Height 6 to to inches. Soft green leaves. Flowers fragrant, white. Of easy cultivation, preferring partial shade.

Strong established plants................... I 25

9 oo $\quad 75$ oo

DICENTRA eximia. Fringed Bleeding-heart. Height io to I 8 inches. Graceful fernlike foliage and deep rose flowers, nodding in slender scape-like racemes all summer. A splendid rock-garden subject.

Medium-size established plants................ I 75 I5 00

I 2500

Strong established, for quick effect............. 3 oo 25 oo

ERYTHRONIUM americanum. Common Troutlily. Height 5 to 10 inches. Green mottled leaves with bright yellow flowers in very early spring. Strong plants....

LILIUM canadense. Canada Lily. Slender stems 2 to 4 feet high. Flowers in various shades of orange, yellow, and red. Very ornamental.

$\mathrm{X}$ strong established first-size flowering bulbs......... I 75

Strong second size (many will flower first season)........ I

I 6 oo

750

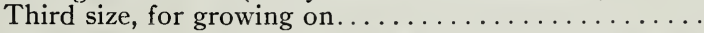

5 oo

I 50 oo

65 oo

carolinianum. Carolina Lily. Height 3 to 4 feet. Leaves verticillate. Flowers orange-red and extremely fragrant. No Lily collection complete without this rare variety.

$\mathrm{X}$ strong established first-size bulbs............. $350 \quad 30$ oo

Second size, for growing on................. I 75 I5 


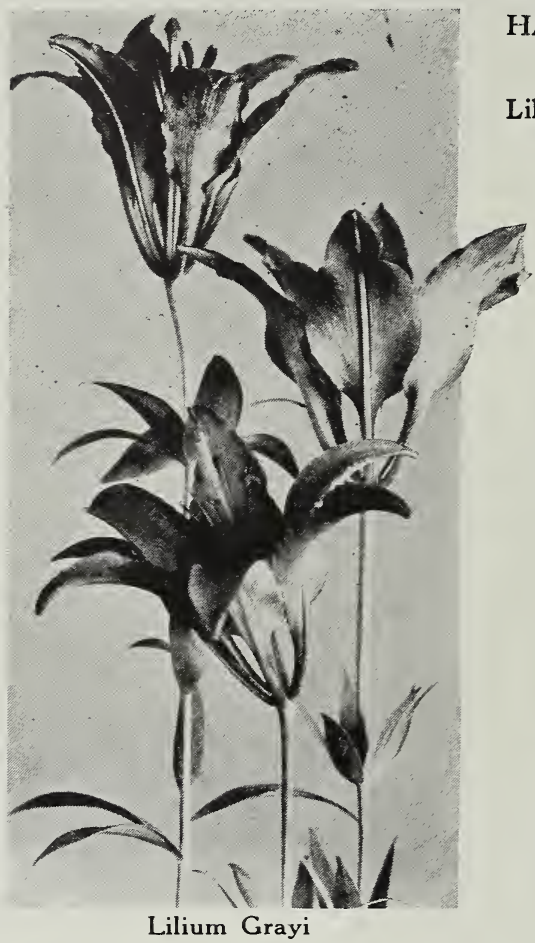

\section{HARDY NATIVE LILIES AND BULBOUS PLANTS, continued}

Lilium Grayi. Gray's Lily. Height 2 to 4 feet. A beautiful Lily, with deep reddish bell-shaped flowers, orange spotted within. Exceedingly showy and continues to grow in demand. My stock is sufficient to meet demands. Early orders solicited.

First-size strong flowering bulbs. $\$ \mathrm{I} .75$ for I0, \$I 5 per IOO, \$I 25 per I,000.

Second size, mostly flowering bulbs. $85 \mathrm{c}$. for Io, $\$ 7.50$ per I00, $\$ 65$ per I,000.

Third size, for growing on. $65 \mathrm{cts}$. for 10 , $\$ 5$ per $100, \$ 40$ per $\mathrm{I}, 000$.

philadelphicum. Orange-cup Lily. Height I to 3 feet. Reddish orange flowers, with purple spots.

Strong first-size flowering bulbs. $\$ \mathrm{I} .75$ for I0, \$I 5 per IOO, \$I35 per I,000.

Strong second-size flowering bulbs. \$I for IO, $\$ 8$ per IOO, $\$ 75$ per I,000.

regale. Royal Lily. Height 2 to 3 feet. Large, white, attractive, fragrant flowers. Finest novelty of the Lily family. Hardy and most beautiful.

First-size strong flowering bulbs. $85 \mathrm{cts}$. each, $\$ 7.50$ for io, $\$ 70$ per ioo.

Strong second size. $\$ 5$ for I0, $\$ 45$ per Ioo.

superbum. American Turkscap Lily. Height 3 to 8 feet. Flowers with dark purple spots; inside of bright orange. The finest and most used American Lily for massing among shrubbery and in border plantings. Often more than forty large flowers on a single stem. We are headquarters for this famous Lily and have more than 75,000 flowering bulbs on hand for autumn delivery Early orders solicited and will have best attention. XX largest select bulbs...........\$3 $00 \quad \$ 27 \quad 50$

First-size. X select flowering bulbs............. I 50 I2 50 \$100 00

Second size. mostly flowering bulbs............. $75 \quad 5 \quad 00 \quad 45 \quad 00$

Third size (many will bloom first season) .......... $50 \quad 4$ oo $\quad \begin{array}{llll}45 & 00\end{array}$

Special offer for trial. 100 assorted Lilies, strong flowering size, prepaid for $\$ 12.50$

TRILLIUM erectum. Purple Trillium. Large; very ornamental, 9 to 18 inches high. Large red fruit, flowers brown to purple. Early, vigorous, spring bloomer. More than 50,000 ready for immediate shipment. Recommended for border and woodland planting.

Largest X select bulbs.................. \$I oo \$7 oo \$60 oo

Strong first size. Real bargain............. $75 \quad 400 \quad 3000$

Second size (majority will bloom first season)....... 40 I 75 I2 50

grandiflorum. Snow Trillium. The finest and largest species. Flowers 2 to 3 inches across, in early spring; white turning to rose color. One of our best spring bloomers. We have more than I00,000 strong flowering bulbs for prompt shipment. It flourishes and blooms to perfection in woodland and border plant- 


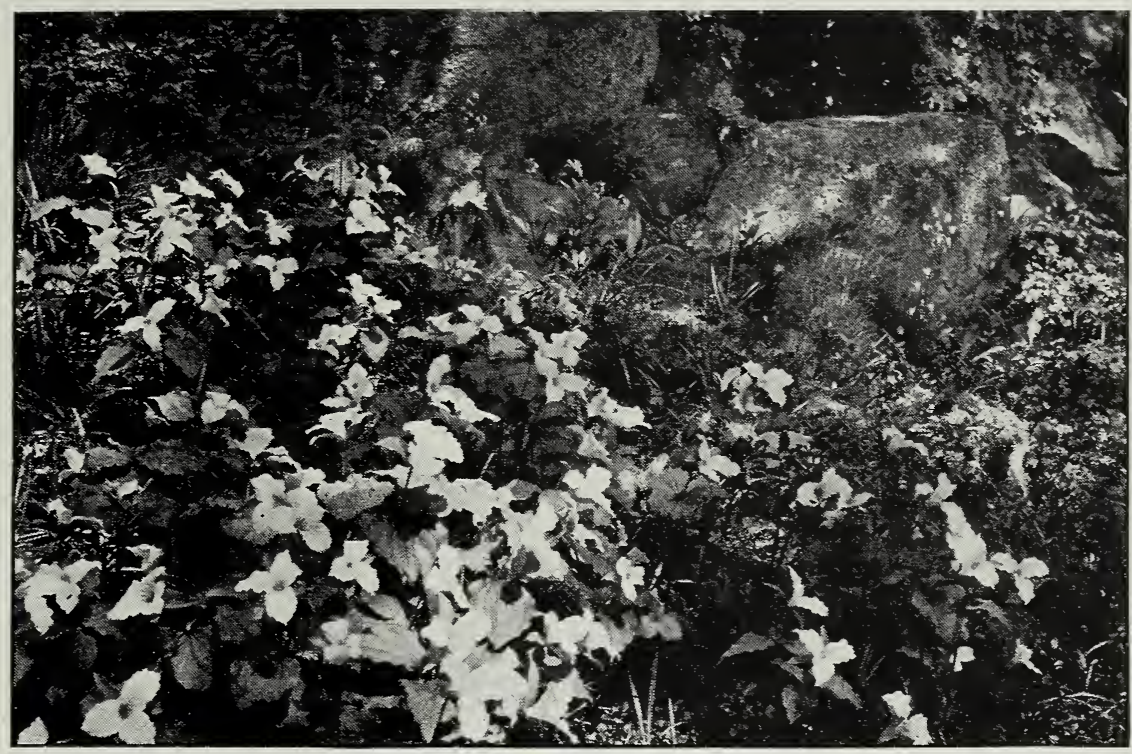

Trillium grandiflorum

\section{HARDY NATIVE LILIES AND BULBOUS PLANTS, continued}

Trillium grandiflorum, continued

Io IOO

$\mathrm{I}, 000$

ings and cannot be recommended too highly for general use. Early orders solicited. Samples will be sent on request.

XXX largest size, unusually heavy............ \$I $25 \quad \$ 8$ oo $\$ \$ 75$ oo

XX first-size heavy bulbs.................. $75+00 \quad 3000$

Strong second size, $\mathrm{X}$ value................. 60 I 25 I0

nivale. Dwarf Trillium. Height + to 6 inches. Drooping white flowers. Western species. Rare.

Strong flowering bulbs................... I 50 I2 50

recurvatum. Prairie Trillium. Height io to is inches.

Strong, erect. Flowers dark purple. Rare western species. Strong flowering bulbs. SI.50 for IO, \$12.50 per 100 .

stylosum. Rose Trillium. Height io to I 8 inches. Large, rose-pink, nodding flowers. Rare and beautiful southern species. Strong flowering size bulbs. $\$$ I for Io, $\$ 7$ per I00, $\$ 60$ per I, 000.

Strong second size, mostly flowering. 60 cts. for $10, \$ 3.50$ per 100, \$30 per I, ooo.

undulatum. Painted Trillium. Very strong, vigorous grower. Height 8 to is inches. Earliest bloomer of all Trilliums. Large flowers with scarlet and white markings. XX strong first-size \$I for Io, \$6.50 per Ioo, $\$ 50$ per I, Ooo.

Strong second size. 60 cts. for Io, $\$ 2.50$ per $100, \$ 20$ per I, 000 .

Special Offer. 100 first-size assorted Trilliums, prepaid for $\$ 6$.

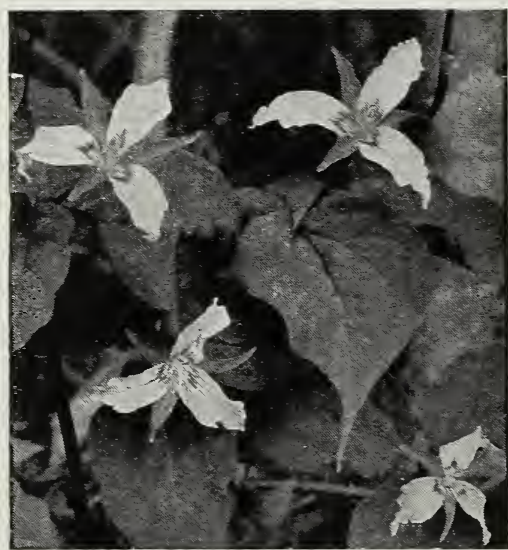

Trillium undulatum 


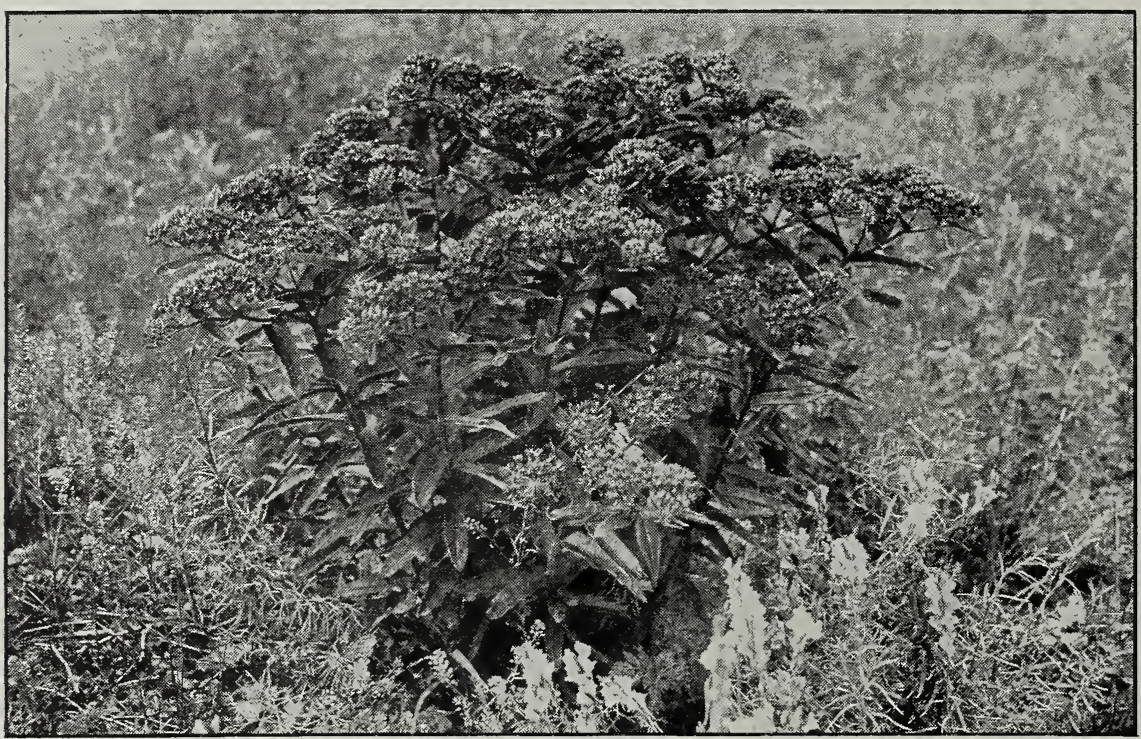

Asclepias tuberosa

\section{Hardy Native Herbaceous Perennials}

This list contains a variety of Herbaceous Plants furnishing a succession of bloom from early spring to late autumn, all having been tried out with success in cultivation. The height specified indicates approximate height of each plant as found in wild state. The time of blooming naturally depends on locality.

ACONITUM uncinatum. Clambering Monkshood. Height 3 ro 100 ז,000 to 6 feet. Blue, hood-shaped flowers.

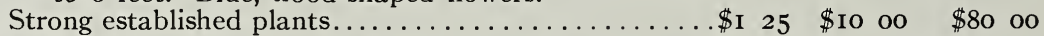

ACT AEA alba. White Baneberry. Height $\mathrm{I} / 2$ to 3 feet. Flowerstalk red; white flowers and berries. Early June.

Strong established plants................... I 25 I0 00

rubra. Red Baneberry. Height I to 3 feet. May. White flowers and red berries. Strong established plants.. I 50 I2 50

ANGELICA Curtisi. Filmy Angelica. Height 3 to 5 feet. Greenish white flowers in August.

Strong established plants................ I oo $750 \quad 6500$

ARALIA racemosa. American Spikenard. Height 2 to 5 feet. Smooth stem; large compound leaves; white panicled flowers in July. Strong established plants........ I 25 Io 00

ASARUM Shuttleworthi. Mottled Wild Ginger. Height 4 to 6 inches. Heart-shaped leaf; flowers purplish brown in June; fragrant.

$\mathrm{X}$ strong established plants................. I 50 I2 50

ARUNCUS sylvester. Goatsbeard. Height 4 to 6 feet. Cut leaves and white flowers in May and June.

$\mathrm{X}$ strong established..................... I 25 Io $00 \quad 8000$

ASCLEPIAS tuberosa. Butterfly Weed. Height I to 2 feet. Very showy. Flowers orange or red.

Strong established plants................... I 50 I2 50 I0o oo

Light grade plants for growing on .............. $80 \quad 600$

ASTER cordifolius. Blue Wood Aster. Height 2 to 4 feet. Free bloomer. Flowers pale blue or nearly white.

Strong plants.....................

$750 \quad 6000$ 
HARDY NATIVE HERBACEOUS PERENNIALS, continued

BAPTISIA australis. Blue Wild-Indigo. Height 3 to 5 feet. io 100 Flowers blue; very showy. Strong established plants.\$I $75 \quad \begin{array}{llll}75 & 00\end{array}$ tinctoria. Yellow Wild-Indigo. Height 2 to 3 feet. Abundant yellow flowers in June. Showy.

$\mathrm{X}$ heavy transplanted...................... I $75 \quad$ 15 $00 \quad \$ 12500$

CAMPANULA divaricata. North Carolina Harebell. Height I to 2 feet. Flowers pale blue, bell-shaped, in July. Good for rockery. Strong established plants...... I 25 Io oo $85 \infty$

CAREX Fraseri. Fraser Sedge. Height 9 to 18 inches. Rare, broad-leaved evergreen. Flowers white in spikes, in March. Best suited for shade.

$\mathrm{X}$ strong established clumpy plants............2 $50 \quad 2000$

CAULOPHYLLUM thalictroides. Blue Cohosh. Height 2 to 3 feet. Yellowish green flowers in April. Fruit blue and showy. X strong established............. I oo $850 \quad 7500$

CHAMAELIRIUM luteum. Fairy Wand. Height $\mathrm{I}$ to 2 feet. Spike of small white flowers in June. Showy.

Strong established plants................... I oo 8 oo 70 oo

CIMICIFUGA americana. American Bugbane. Height 3 to 6 feet. Flowers showy white, in August. Leaves divided. Strong established................. I 25 Iо oo

racemosa. Cohosh. 4 to 8 feet. Flowers white; decompound leaves. $X$ strong plants................... I $25 \quad 8$ oo 7500

CLINTONIA borealis. Bluebead. Height 6 to 12 inches. Greenish yellow flowers. Showy species. June.

Strong established plants.................. I 25 Io $00 \quad 8500$ umbellulata. Speckled Clintonia. Height 9 to 15 inches. Fragrant white flowers in June.

Strong established plants................... I oo 8 оо

COREOPSIS lanceolata. Lance Coreopsis. Height 2 to 4 feet. Free yellow bloomer. July. Strong estab. plants.. I 25 10 oo

DIPHYLLEIA cymosa. Umbrella ro Ioo Leaf. Height I to 3 feet. Large-1 obed leaves. Flowers white, in May. Purple showy fruit in bunches. Prefers moist location. Strong established plants................ \$I 25 \$I oo

DISPORUM lanuginosum. Fairy Bells. Height I to 3 feet. Greenish flowers in May. Fruit red and drooping.

Strong established plants..... I 25 I0

DODECATHEON meadia. Common Shooting Star. Height 9 to 18 inches. Flowers pink, purple, and white. Extremely showy. April. Strong established plants. I 50 I2 50

EUPATORIUM purpureum. JoePye-Weed. Height 4 to 8 feet. Flowers purple, in large panicles in June.

$\mathrm{X}$ strong established plants... I 25 Io oo urticæfolium. Snow Thoroughwort. Height 3 to 4 feet. Flowers white, late in Aug.

Strong established plants..... I,000, $\$ 70 \ldots$ I oo 8 oo

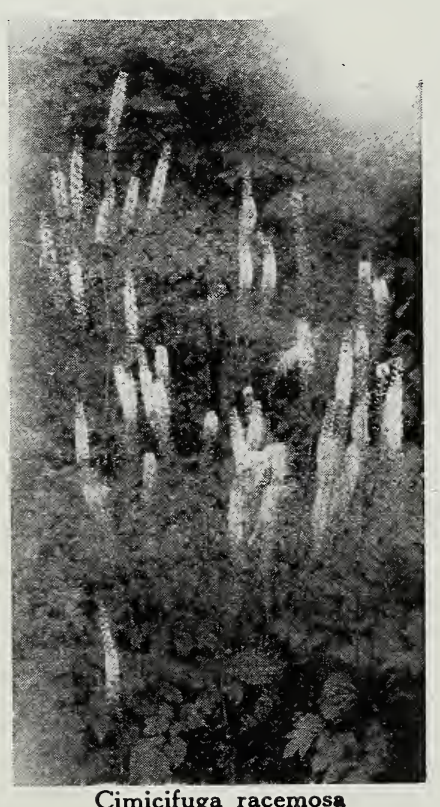

Cimicifuga racemosa 


\section{HARDY NATIVE HERBACEOUS PERENNIALS, continued}

EUPHORBIA corollata. Flowering Spurge. Height I to 4 io Ioo

$\mathrm{I}, \mathrm{OOO}$ feet. Flowers white, in August.

Strong established .....................\$I $25 \$$ IO 00

GENTIANA Andrewsii. Closed Gentian. Height io to I8 inches. Foliage green; blue closed flowers in September. Strong established plants............ I oo

Medium-size plants for growing on ............ 50

GEUM montanum. Mountain Avens. Height 6 to 18 inches. Showy yellow flowers in June. Well suited to rockgardens. Strong established..............

GILLENIA stipulata. Indian Physic. Height 2 to 4 feet. Handsome cut foliage. Flowers pure white or rosetinted, in June. Splendid for massing among shrubbery. X strong established plants......... I

HELENIUM autumnale. Common Sneezeweed. Height 3 to 5 feet. Flowers handsome, yellow, in August.

$\mathrm{X}$ strong established flowering clumps........... I oo 8 oo 70 oo

HEPATICA acutiloba. Sharplobe Hepatica. Height 5 to Io inches. White and purple flowers in March and April.

Strong established plants................. I oo 8 oo 70 oo

triloba. Roundlobe Hepatica. Height 6 to 8 inches. Flowers blue, purplish, or white, in April.

Strong established plants................. I 25 Io oo

HEUCHERA americana. American Alumroot. Height I to 2 feet. Large-lobed leaves. Coloring beautiful, mottled bronze in early winter. Flowers greenish white in June. Splendid rock-garden subject.

$\mathrm{X}$ strong established plants............... I

villosa. Hairy Alumroot. Height 12 to $\mathrm{I} 8$ inches. Good for rockery. Flowers white, in August.

Strong established clumps................. I 25 Io

8500

IO 00

I0 $00 \quad 8500$

HOUSTONIA purpurea. Mountain Houstonia. Height 6 to I 8 inches. Purple flowers in July.

Strong established clumps................. I 25 Io oo

8500

HYDRASTIS canadensis. Golden Seal. Height to to 20 inches. A medical herb of great value. We have a large stock of this item on hand and can make prompt shipment on sizes named and seeds.

One-year strong established plants............. I oo

Two-year strong established plants.................. 25

Three-year, $\mathrm{X}$ strong established plants...........

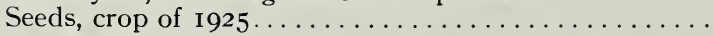

NOTE: Special prices for large quantities of seeds or plants.

IRIS Kaempferi. Japanese Iris. Finest species. Assorted colors. $\mathrm{X}$ strong established plants............

2

montana. Dwarf Gayfeather. Showy Alpine variety.
I to $\mathrm{I} / 2$ feet high. Flowers purple, in spikes, in July.

Strong established plants............... 250

spicata. Spike Gayfeather. Height 3 to 5 feet. Purple

flower-spikes in August. Strong established plants.. I 75
OBELIA cardinalis. Cardinal Flower. Height 3 to 5 feet.

600

900

I 750

50

50 OO

7500

I60 00

350

20 OO I 80 Oo

LIATRIS montana. Dwarf Gayfeather. Showy Alpine variety. Showy scarlet flowers in August.

$\mathrm{X}$ strong plants....................... I 50

2000

I 500

I $250 \quad$ IOO 00

syphilitica. Large Blue Lobelia. Height i to 3 feet. Flowers large, blue, last of August.

$\mathrm{X}$ strong established plants.

I 50

IOO OO 


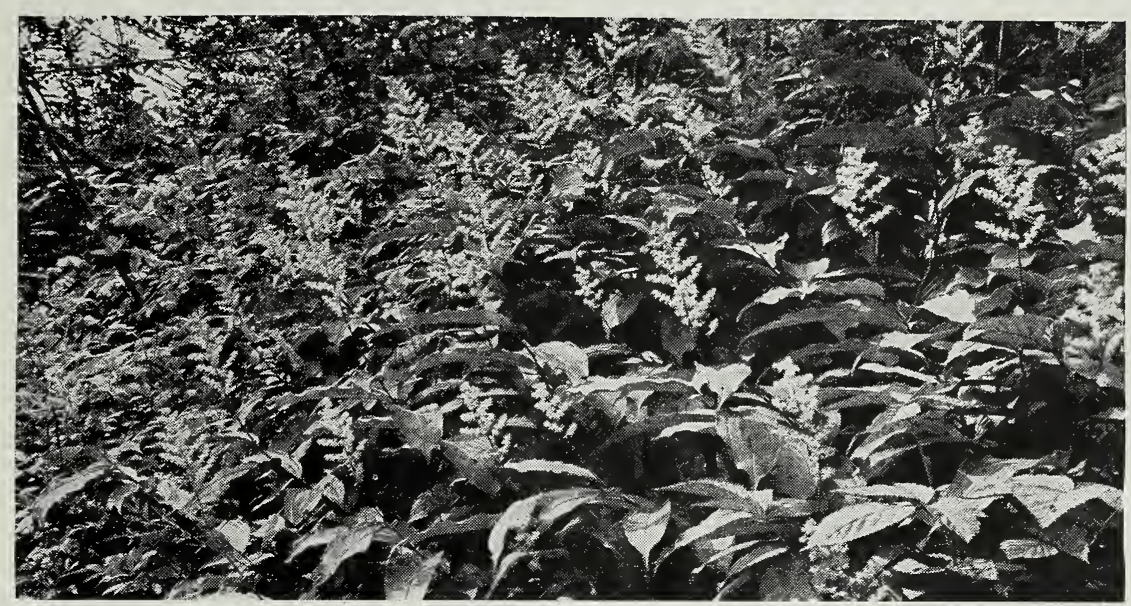

Smilacina racemosa (False Solomon Seal)

HARDY NATIVE HERBACEOUS PERENNIALS, continued

PANAX quinquefolium. American Ginseng. Height I to 3 ro 100

feet. Great Chinese medical herb, fast becoming

rare and scarce. We have splendid stock in all sizes

on hand ready for prompt shipment.

One-year established plants.................\$I oo

Two-year strong established plants............. I 25

Three-year, $\mathrm{X}$ heavy stocky plants............. I 75

Seeds, crop of 1925 .

Special quotations on large quantities of seeds and plants

$\$ 600$

800

I 5 OO

50

$\$ 50$ oo

7500

I 2500

350

PHLOX divaricata. Blue Phlox. Height 9 to $\mathrm{I} 8$ inches. Blue

flowers in May or June................... I 50

pilosa. Downy Phlox. Height i2 to 20 inches. Flowers

pink or rose color. August............... I 50

1250

1250

PODOPHYLLUM peltatum. May Apple. Height I to I $1 / 2$ feet. Large light green leaves. White flowers in May. Prefers shade. Strong established plants.... I oo 8 oo

7500

POLYGONATUM commutatum. Great Solomon Seal. Height 3 to 6 feet. Drooping greenish white flowers in June. XX strong established plants.......... I to 3 inches high. Foliage coloring beautiful brilliant bronze in winter. White flowers in July. From high altitude. Very desirable rock-garden subject.

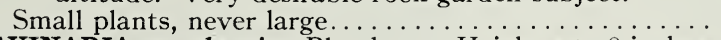

SANGUINARIA canadensis. Bloodroot. Height 5 to 8 inches. One of our best perennials. Large white flowers in early spring. Strong established plants...........

SAXIFRAGA Michauxi. Michaux Saxifrage. Height 9 to 18 inches. Rare Alpine variety. Flowers white with pink markings. Strong established plants....... 3 oo

2500

SILENE stellata. Starry Campion. Height 2 to 4 feet. Flowers in white showy panicles in July............ I 25

virginica. Fire Pink. Very showy crimson flowers in June.

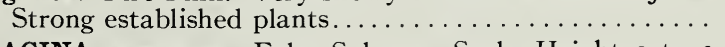

SMILACINA racemosa. False Solomon Seal. Height 2 to 3 feet. White flowers in June. Red speckled berries in

August. Strong established plants..............
SOLIDAGO odora. Fragrant Goldenrod. Height 2 to 4 feet. Yellow flowers in August and early September...... I 25 10 00 80 


\section{HARDY NATIVE HERBACEOUS PERENNIALS, continued}

STENANTHIUM robustum. Feather Fleece. Long, white, ro 100 I, 000 delicate flowers on stems 3 to 5 feet high in late summer. Extremely ornamental and altogether one of our finest perennials. Thrives in damp situations as well as in drier soil.

XX largest first-size, well-established plants.......\$I 50

Strong second blooming size.................. I oo

Strong third size for growing on .............. 75

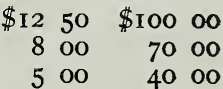

THALICTRUM dioicum. Early Meadow Rue. Height 2 to 4 feet. Odd greenish flowers in May. Attractive cut foliage. Established plants................. I 75

I5 OO

THERMOPSIS caroliniana. Carolina Thermopsis. Height 3 to 5 feet. Very showy yellow flowers in large terminal racemes in June. Strong established plants. 2 oo

UVULARIA perfoliata. Wood Merrybells. Height 6 to $\mathrm{I} 8$ inches. Pale yellow flowers in early spring.

Strong established plants................... I oo

sessilifolia. Little Merrybells. Height io to 20 inches. Yellow flowers in May. Strong established plants.. I oo

VIOLA blanda. Sweet White Violet. Height 2 to 4 inches. Fragrant white flowers in early spring.

Strong established clumps.................. I oo

cucullata. Blue Marsh Violet. Height 6 to ro inches. Blue flowers all summer. Strong established plants...... I oo

pedata. Birdsfoot Violet. Height 3 to 7 inches. Showy blue flowers in May. Strong established plants.... I oo

pedata bicolor. Two-color Birdsfoot Violet. Height 4 to 6 inches. Velvety light blue and purple flowers in May. Rare and beautiful, pansy-like.

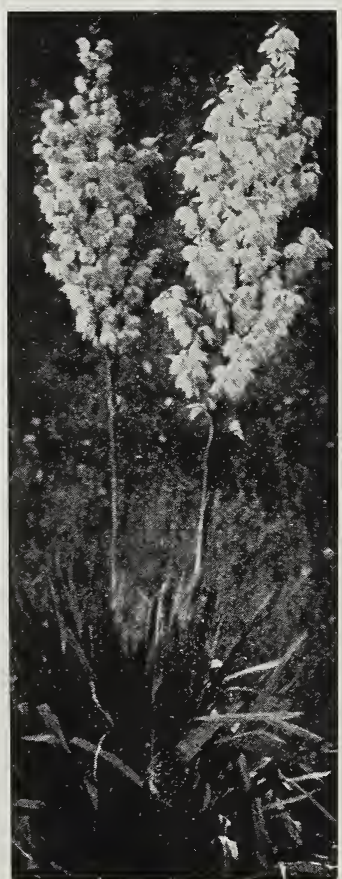

Yucca nlamentosa
Strong established........ I 75

8 oo

8 oo

850

I5 OO

12500

rotundifolia. Roundleaf Violet. Height 3 to 4 inches. Large yellow flowers in early spring. Large prostrate shining leaves. Strong established..................

sagittata. Arrowleaf Violet. I 00 850 7500 Height 4 to 8 inches. Deep blue flowers in May. Strong established plants.. I oo

XEROPHYLLUM asphodeloides. Turkeysbeard. Height 3 to 5 feet. Long grass-like leaves. Tall spikes of very attractive white flowers. Rock-garden subject.

Heavy established clumpy plants ............. 300

20000

YUCCA filamentosa. Common Yucca. Height 3 to 8 feet. Large white panicles of flowers in July and August.

$\mathrm{X}$ strong established clumpy plants............. 3 oo

Strong two-year nurserygrown seedlings ......... glauca. So p w e ed Yucca.
Height 2 to 5 feet. Stiff narrow leaves. White flowers in June and July.

Two-year strong nurserygrown seedlings ......... 


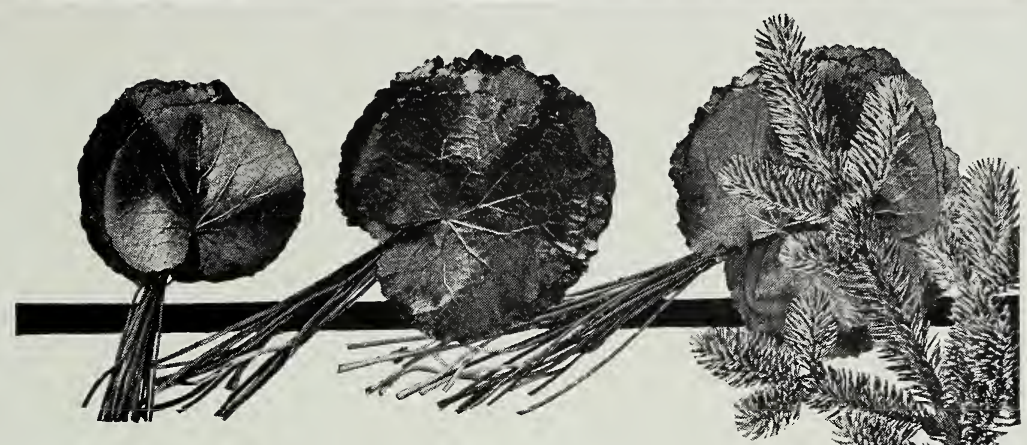

\section{Southern Evergreens \\ for \\ Holiday Greetings}

A box of fresh, fragrant evergreens from the Blue Ridge, redolent with the odor of Pine and Balsam and brilliant with Galax and Holly.

Can you imagine anything more in keeping with the Christmas season, or that will convey in such unique fashion your Christmas message?

These Christmas greens are carefully selected, and skillfully packed, which insures delivery in perfect condition. The keeping qualities are unsurpassed under ordinary conditions, and even in warm rooms they will retain for days their freshness and brilliant natural colorings.

\section{PRICES PREPAID}

Cash with order from unknown parties GALAX LEAVES. Medium and small sizes, green or bronze. . . . per $1,000 \$ 3.00$

Large selected sizes ....... per I,000 4.00 LEUCOTHOË SPRAYS. Beautiful foliage, naturally in the shape of a partial garland or wreath. Extremely decorative. Deep green or rich bronze. I to $2 \mathrm{ft}$..... per roo

BALSAM FIR. Choice branches I to 2 ft. long; woodsy fragrance.per doz.

BALSAM NEEDLES and TWIGS, clipped for pillows........ Io lbs. 3.00

GROUND PINE (Bouquet Green). Very effective............ 5 lbs. 4.00 AMERICAN HOLLY. (Branches). Deep green leaves with bright red berries. I to $2 \mathrm{ft}$. . . . . . per doz. 4.00

\section{SPECIAL PREPAID BOX PRICES} Order by mail or wire

CASE N. 500 Assorted Galax and introductory assortment made up from list opposite. Splendid value, to set acquainted...........\$3.00

CASE O. I, ooo Assorted Galax, with extra-nice assortment from all of list opposite............ 5.00

CASE P. 2,000 Assorted Galax, 50 I_eucothoë Sprays, 25 Fern Sprays, 6 Fir branches, I lb. Bouquet Green, and 6 sprays choice Holly.

CASE Q. 4,000 Assorted Galax and extra quantities of all list opposite. This beautiful collection will be enough for yourself and to divide with all your neighbors. XX Special Value......... I2.50 


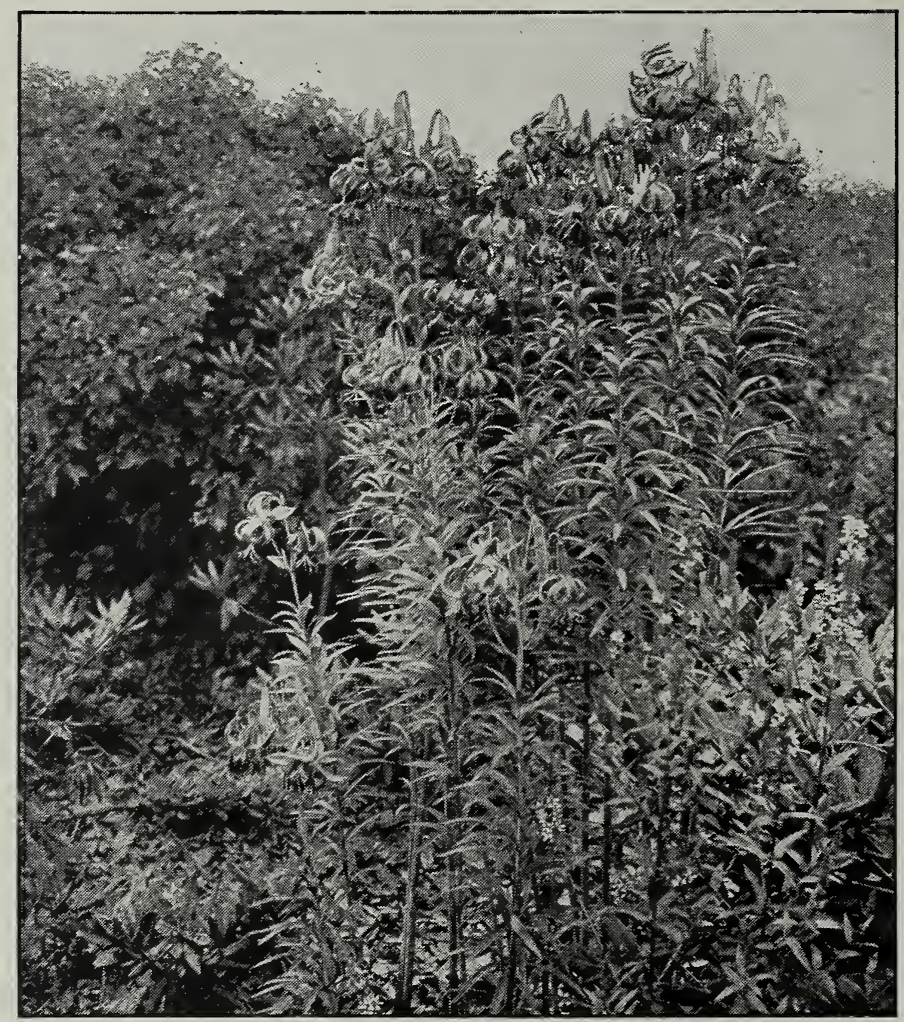

LILIUM SUPE.RBUM. See page 24

\section{MY SPECIALTIES}

Pieris floribunda, Azaleas, Rhododendrons, Kalmias Oxydendrum, Tsugas, Leucothoe Catesbæi, Zanthorhiza, Iris Galax, Shortia, Ferns, Cypripediums, Dicentra, Liliums Trilliums, Hydrastis, Panax, Polygonatum Sanguinaria and Stenanthium

Landscape, Architects, Nurserymen, and Large Planters find my stock particularly suited to their requirements. Those who have known me longest are the largest users of my products. Prices reasonable to the extreme, quality considered. Your correspondence is invited and your orders will be given good attention. Send me your list of requirements quickly as possible to insure getting the stock in good time for planting. Prices named include all packing cost and delivery to our station.

SPECIAL PRICE ALLOWED ON LARGE ORDERS

E. C. ROBBINS

ASHFORD, McDOWELL COUNTY NORTH CAROLINA 